\title{
Molecular pathogenesis of Wilson and Menkes disease: correlation of mutations with molecular defects and disease phenotypes
}

\author{
P de Bie, P Muller, C Wiimenga, L W J Klomp
}

J Med Genet 2007;44:673-688. doi: 10.1136/jmg.2007.052746

The trace metal copper is essential for a variety of biological processes, but extremely toxic when present in excessive amounts. Therefore, concentrations of this metal in the body are kept under tight control. Central regulators of cellular copper metabolism are the copper-transporting P-type ATPases ATP7A and ATP7B. Mutations in ATP7A or ATP7B disrupt the homeostatic copper balance, resulting in copper deficiency (Menkes disease) or copper overload (Wilson disease), respectively. ATP7A and ATP7B exert their functions in copper transport through a variety of interdependent mechanisms and regulatory events, including their catalytic ATPase activity, copper-induced trafficking, post-translational modifications and protein-protein interactions. This paper reviews the extensive efforts that have been undertaken over the past few years to dissect and characterise these mechanisms, and how these are affected in Menkes and Wilson disease. As both disorders are characterised by an extensive clinical heterogeneity, we will discus how the underlying genetic defects correlate with the molecular functions of ATP7A and ATP7B and with the clinical expression of these disorders.

See end of article for authors' affiliations

Correspondence to: LW J Klomp, Laboratory of Metabolic and Endocrine

Diseases, Room KC.02.

069.1, Lundlaan 6, 3584

EA Utrecht, The

Netherlands; I.klomp@ umcutrecht.nl

Received 2 July 2007

Revised 14 August 2007

Accepted 15 August 2007

Published Online First

23 August 2007
M any trace elements require a delicate homeostatic balance to ensure that the needs for normal cellular processes are met, but at the same time, toxicity due to excessive accumulation of these elements needs to be prevented. Copper is an excellent example of such a trace element. It is required for numerous cellular processes, including mitochondrial respiration, antioxidant defence, neurotransmitter synthesis, connective tissue formation, pigmentation, peptide amidation and iron metabolism (table 1). However, in amounts that exceed cellular needs, copper is highly toxic, owing to its potential to facilitate the production of reactive oxygen species by means of Fenton chemistry. ${ }^{2}$ Refined mechanisms have evolved to regulate intake, excretion and the cellular distribution of copper (Box 1). The importance of these regulatory mechanisms is underlined by several hereditary human disorders of copper homeostasis. These disorders can broadly be divided into two classes; (1) diseases associated with copper deficiency (Menkes disease (MD), OMIM 309400; ${ }^{3}$ and occipital horn syndrome (OHS), OMIM 304150), and (2) diseases associated with copper excess (Wilson disease (WD),
OMIM 277900; ${ }^{4}$ Indian childhood cirrhosis (ICC), OMIM 215600; ${ }^{5}$ endemic Tyrolean infantile cirrhosis (ETIC), OMIM 215600; ${ }^{6}$ and idiopathic copper toxicosis (ICT); OMIM $215600^{78}$ ). The clinical expression of several of these disorders is highly heterogeneous. In this review, we discuss both the genetics and molecular-functional defects underlying $\mathrm{MD}$ and $\mathrm{WD}$, the genotype-phenotype correlations of these disorders and how such correlations might be explained by the molecular-functional defects. Additional information of interest to the reader, but not essential to the scope of this review, is provided in the text boxes.

\section{Copper-transporting ATPases and human disease}

Diseases associated with copper deficiency MD is an X-linked recessive disorder characterised by a general copper deficiency. ${ }^{39}$ The incidence of the disease is estimated to range between 1:40 000 and 1:350 000..$^{10-12}$ Clinical features of MD are a direct consequence of dysfunction of several copper-dependent enzymes (cuproenzymes; table 1), secondary to an inability to load these enzymes with copper. Based on the symptoms, two forms of MD have been described; classic MD and mild MD, a less severe form. The clinical features of classic MD typically comprise neurological defects (severe mental retardation, neurodegeneration, seizures), growth retardation, hypothermia, laxity of skin and joints, hypopigmentation, and peculiar "kinky" or "steely" hair. ${ }^{13-15}$ Patients present at 2-3 months of age, and owing to the severity of the disorder, death usually occurs by 3 years of age. Patients with mild MD have a longer lifespan, and in these patients the neurological defects in particular are less profound. ${ }^{16-18}$ OHS (also known as X-linked cutis laxa, or EhlersDanlos syndrome type IX) is allelic to MD and its symptoms generally overlap, with the most notable exception being that neurological abnormalities

Abbreviations: A-domain, actuator domain; AIPP1, ATPase interacting PDZ protein 1; CCS, copper chaperone for superoxide dismutase $1 ; C T$, copper toxicosis in Bedlington terriers; CTR1, copper transporter 1; ER, endoplasmic reticulum; ETIC, endemic Tyrolean infantile cirrhosis; ICC, Indian childhood cirrhosis; ICT, idiopathic copper toxicosis; LEC, Long-Evans cinnamon; MBS, metalbinding site; MD, Menkes disease; $N$-domain, nucleotidebinding domain; NF, nuclear factor; OHS, occipital horn syndrome; OMIM, Online Mendelian Inheritance in Man; Pdomain, phosphorylation domain; PLZF, promyelocytic leukemia zinc finger protein; SOD1, superoxide dismutase 1; TGN, trans-Golgi network; WD, Wilson disease 
Table 1 Functions of copper-dependent enzymes

\begin{tabular}{|c|c|c|}
\hline Enzyme & Function & Consequences of deficiency \\
\hline Caeruloplasmin & Iron and copper transport & $\begin{array}{l}\text { Decreased circulating copper levels, iron } \\
\text { deficiency }\end{array}$ \\
\hline Cytochrome $\mathrm{C}$ oxidase & Mitochondrial respiration & Hypothermia, muscle weakness \\
\hline $\begin{array}{l}\text { Dopamine } \beta \text {-hydroxylase } \\
\text { Lysyl oxidase }\end{array}$ & $\begin{array}{l}\text { Catecholamine production } \\
\text { Connective tissue formation }\end{array}$ & $\begin{array}{l}\text { Hypothermia, neurological defects } \\
\text { Laxity of skin and joints }\end{array}$ \\
\hline $\begin{array}{l}\text { Peptidylglycine } \alpha \text {-amidating mono- } \\
\text { oxygenase }\end{array}$ & Peptide amidation & Neuroendocrine defects \\
\hline $\begin{array}{l}\text { Superoxide dismutase } \\
\text { Tyrosinase }\end{array}$ & $\begin{array}{l}\text { Antioxidant defence } \\
\text { Pigment formation }\end{array}$ & $\begin{array}{l}\text { Diminished protection against oxidative stress } \\
\text { Hypopigmentation of hair and skin }\end{array}$ \\
\hline
\end{tabular}

are far less severe or even absent in OHS. Patients with OHS present with slightly subnormal intelligence and seizures are generally absent. Connective tissue abnormalities represent the predominant features of OHS. Characteristic is the formation of occipital exostoses resulting from calcification of the trapezius and sternocleidomastoid muscles at their attachments to the occipital bone. ${ }^{13} 19$ Treatment of MD consists of copper replacement therapy in which the following fundamental issues should be taken into consideration: (1) the block in intestinal absorption of copper must be bypassed, (2) patients must be identified and treatment started as early in life as possible, (3) circulating copper must be delivered to the brain, and (4) copper must be available within cells for cuproenzyme biosynthesis. ${ }^{20}{ }^{21}$ The only currently available treatment option consists of administration of copper-histidine, a naturally occurring copper-amino acid complex in serum. ${ }^{22}{ }^{23}$ Although copper replacement therapy with copper histidine results in significant improvement in some patients, leading to an increased lifespan, it has not been uniformly beneficial and the prognosis of patients with classic MD remains inevitably poor. The age at which treatment is started and the severity of the disease seem to be among the main determinants for the outcome of this treatment. ${ }^{20} 24$

Both MD and OHS are caused by mutations in the ATP7A gene, ${ }^{18}{ }^{25-27}$ which encodes a highly conserved copper translocating $\mathrm{P}(\mathrm{IB})$-type ATPase with orthologues present in eukaryotes, prokaryotes and archaea. ${ }^{28}$ ATP7A mRNA is expressed in a wide range of human tissues, but its expression is notably low and sometimes even undetectable in the adult liver. ${ }^{25} 27$ The ATP7A polypeptide contains several conserved domains required for ATPase function and copper binding (Box 2). It has been estimated that one-third of MD cases arise from de novo mutations. ${ }^{13}$ Over $200 \mathrm{MD}$-causing mutations have been identified, among which small deletions/insertions, nonsense mutations, missense mutations, and splice site mutations are represented with equal frequency. ${ }^{29}{ }^{30}$ Small deletions/insertions and nonsense mutations are found throughout the whole gene. In contrast, missense mutations are almost exclusively distributed between the first transmembrane domain and the stop codon. The relative lack of MD-causing or OHS-causing missense mutations within the six metal-binding sites (MBSs) located in the amino terminal tail suggests that functional redundancy exists among these six MBSs. Splice-site mutations are mostly clustered between exons 6 and 8, which encode a region just upstream of the first transmembrane domain, and between exons 21 and 22, a region encoding the last transmembrane domain. Interestingly, splice site mutations appear to be over-represented in patients with OHS. ${ }^{29} 30$

Several mouse models for MD and OHS have been described, collectively known as mottled mice. ${ }^{31}$ The mottled mouse phenotypes show a similar variability, as seen between MD and OHS patients. The dappled subtype displays the most severe phenotype; affected mice usually die during prenatal development. In contrast, blotchy mice display a milder phenotype, reminiscent of OHS. Both dappled and blotchy, as well as other mottled subtypes, are caused by mutations in $A t p 7 a$, the murine orthologue of $A T P 7 A .^{32-42}$ Transgenic expression of ATP7A in mottled mice of the brindled subtype rescues the phenotype and partially restores the copper balance. ${ }^{43}$ Calamity, a zebrafish mutant defective in the orthologue of ATP7A (atp7a), has recently been bred. ${ }^{44}$ Calamity zebrafish display a general copper deficiency phenotype and form an excellent model to study the function of atp $7 a$ in the developing zebrafish.

\section{Diseases associated with copper excess}

WD is an autosomal recessive disorder characterised by defective copper excretion, with an estimated incidence between 1:30000 and 1:100 000. ${ }^{45}$ Clinical features of WD result from toxic accumulation of copper, primarily in the liver and the brain, and therefore may include hepatic abnormalities (cirrhosis and chronic hepatitis, culminating in progressive liver failure), neurological defects (parkinsonian features, seizures), and psychiatric symptoms (personality changes, depression, psychosis). ${ }^{45} 46$

In some severe cases, patients present with fulminant liver failure. A characteristic feature often found in patients with WD is the Kayser-Fleischer ring, a deposition of copper in the Descemet membrane visible as a gold-brown ring around the periphery of the cornea. In addition, serum levels of the cuproenzyme caeruloplasmin are often found greatly reduced in patients with WD as a result of rapid degradation of the copperfree form of caeruloplasmin formed in patients with WD. ${ }^{47} 48$ This type of caeruloplasmin deficiency is distinct from acaeruloplasminaemia, a disorder of iron metabolism caused by mutations in the caeruloplasmin gene. ${ }^{49}$ The presentation of WD is strongly heterogeneous, even among patients with the same mutations. Differences have been found in age at presentation, severity of the disease and the predominance of hepatic versus neurological symptoms. ${ }^{48}$ Treatment of WD focuses on two aspects: (1) copper excretion from the body must be promoted, and (2) copper absorption from the diet must be reduced..$^{45}$ The first aspect is best accomplished by copper chelation therapy using penicillamine, ${ }^{50}$ trientine $^{50}$ or ammonium tetrathiomolybdate. ${ }^{51}{ }^{52}$ The latter remains under clinical trial, but seems particularly promising as, when taken with meals, this compound also prevents absorption of copper from the diet. Dietary copper absorption is also efficiently inhibited by zinc ingestion and by omitting copper-rich dietary components. Controversy exists as to which approach constitutes the more effective treatment regimen, and proper randomised control studies to clarify this issue are lacking. In some cases, the preferred method includes initial copper chelation followed by zinc therapy to prevent remission of high copper concentration in the liver. In general, these treatment options are very effective; however, if treatment is 
ineffective, or in circumstances of fulminant liver failure, liver transplantation provides an effective cure.

The gene mutated in WD, $A T P 7 B$, encodes a coppertransporting P-type ATPase that is highly homologous to $A T P 7 A .^{53-56}$ The expression pattern of $A T P 7 B$ is strikingly different to that of $A T P 7 A$, as $A T P 7 B$ is most abundantly expressed in the liver. Other tissues that express $A T P 7 B$ include kidney, brain, lung, heart, mammary gland and placenta..$^{53}$ 56-58 Almost 300 mutations in $A T P 7 B$ that are associated with WD development have been described. ${ }^{59}$ In contrast to $\mathrm{MD}$, relatively few small insertions/deletions and splice site mutations have been identified in patients with WD; in fact, almost $60 \%$ of all identified WD-causing mutations are missense mutations. The distribution of these mutations over $A T P 7 B$ is similar to the distribution of MD-causing missense mutations in ATP7A. ${ }^{30}$ Although most WD-causing mutations are rare and only reported in single families, some are more common and account for a large portion of WD cases. The most prevalent mutations are H1069Q in Europe and North America, and R778L in southeast Asia. ${ }^{60}$

ICC, ETIC and ICT form a second class of copper-overload disorders that are distinct from WD. ${ }^{61}{ }^{62}$ Most patients with ICC, ETIC and ICT die at an early age due to liver failure as a consequence of decompensated liver cirrhosis. Neurological defects are not found in ICC, ETIC or ICT. Phenotypic expression of ICC, ETIC and some cases of ICT appears to be associated with both an excessive copper intake and an underlying genetic defect. ${ }^{56863}$ Attempts to identify the genetic causes for these disorders have remained unsuccessful, although several candidate genes, including $A T P 7 B$, have been excluded. ${ }^{61}{ }^{62}$

Several animal models of copper overload diseases have been described. ${ }^{64}$ Long-Evans cinnamon (LEC) rats and toxic-milk mice suffer from abnormalities in the Atp $7 b$ gene, making these valid spontaneous models for WD. ${ }^{65-70}$ In addition, an engineered Atp $7 b$ knockout mouse had recently been generated. ${ }^{71}$ The hepatic abnormalities seen in both the LEC rat and the toxic-milk mouse closely resemble those found in WD, but neurological defects have only been found in the Atp $7 b$ knockout mouse, but not in the LEC rat nor in the toxic-milk mouse. ${ }^{6471}$ Another interesting animal model characterised by hepatic copper overload is copper toxicosis (CT) in Bedlington terriers.${ }^{72}$ Pathophysiologically, CT is similar to WD, although neurological defects have not been found and serum caeruloplasmin concentrations are normal. Furthermore, linkage analysis has excluded $A t p 7 b$ as a candidate gene for CT, suggesting that CT is more likely to be a model for ICC, ETIC or ICT. ${ }^{73}$ Using positional cloning approaches, a deletion in COMMDI (formerly MURRI), resulting in complete absence of the COMMDl protein, was identified as a genetic cause for CT. ${ }^{75-77}$ This observation initially led to the suggestion of COMMDI as a candidate gene for human copper overload disorders. However, no disease-causing mutations in COMMDI have been detected in several cohorts of patients with WD, ICC, ETIC or ICT $^{61}{ }^{78-82}$ Possibly, other genetic causes for CT in Bedlington terriers exist, as no mutation in COMMDI could be detected in several pedigrees with affected dogs. ${ }^{83}$ Nine homologues of COMMDI have recently been reported, which should be prioritised in the search for alternative genetic causes of $\mathrm{CT}^{85}$

\section{Functions of copper-transporting ATPases}

The physiological functions of ATP7A and ATP7B can largely be deduced from the observed phenotypes in $\mathrm{MD}$ and $\mathrm{WD}$, respectively. In $\mathrm{MD}$, copper transfer across the mucosal barrier is impaired, whereas in WD hepatic excretion of copper into the bile is reduced, suggesting that both proteins are rate limiting for cellular copper export. Biochemical and clinical observations in patients with $\mathrm{MD}$ or WD suggested an additional role for ATP7A and ATP7B in cuproenzyme biosynthesis, as markedly reduced copper incorporation of several cuproenzymes has been found in MD and WD. ${ }^{47} 86-90$

\section{Regulation of cellular copper export}

Direct evidence for a copper export function of ATP7A and ATP7B came from cell culture studies showing that absence of ATP7A in MD-derived patient fibroblasts resulted in cellular copper accumulation and increased copper retention, despite normal copper uptake rates. ${ }^{91}$ This copper retention phenotype could be corrected by expression of either ATP7A or ATP7B. ${ }^{92}$ Consistent with these observations, overexpression of ATP7A or ATP7B in a variety of cell lines results in a decrease in copper accumulation and retention, and in an increased tolerance to elevated environmental copper levels. ${ }^{93-95}$ Direct proof for the actual copper translocation function of these proteins came from studies showing that overexpression of ATP7A or ATP7B resulted in increased translocation of ${ }^{64} \mathrm{Cu}$ into isolated membrane vesicles, which has also been shown using purified ATP7A reconstituted in soybean asolectin liposomes.96-98 Taken together, these data suggest that both ATP7A and ATP7B function as ATP-dependent copper export pumps. The difference in phenotype between MD and WD is mainly determined by differences in tissue distribution and cellular localisation of ATP7A and ATP7B, as discussed below. Unfortunately, the effects of MD-causing and WD-causing mutations on the copper transport activity of ATP7A and ATP7B have only been determined using complementation assays of $\Delta C c c 2$ yeast. Although these yeast studies have clearly shown the inability of mutated ATP7A and ATP7B proteins to mediate copper delivery to the secretory pathway, no studies have yet been performed to directly elucidate the effects of disease-associated mutations on the transport activity of ATP7A and ATP7B. Significant efforts are currently being made to develop several new tools that allow detection of changes in intracellular copper concentrations and bioavailability. ${ }^{99-102}$ We have developed an MRE-luciferase reporter, which is a sensitive and robust tool to assess the ability of ATP7A and ATP7B to exort copper from the cytosol, and appears useful to assess the effects of MD-causing and WD-causing mutations on cytosolic bioavailable copper (van den Berghe and Klomp, unpublished observations).

\section{Regulation of cuproenzyme biosynthesis}

Loss of function of several cuproenzymes is a characteristic feature of both MD and WD. Using fibroblasts isolated from patients with MD or mottled mice, it has been shown that ATP7A deficiency directly results in reduced activities of the copper-dependent enzymes lysyl oxidase, tyrosinase, cytochrome C oxidase, extracellular superoxide dismutase and peptidylglycine $\alpha$-amidating mono-oxygenase. ${ }^{86-90}$ Although not consistently found among all patients, WD is often associated with a dramatic reduction in serum caeruloplasmin levels as a result of rapid degradation of the copper-free form of caeruloplasmin secreted from the hepatocytes of patients with WD. ${ }^{47} 48$

In yeast, the orthologue of ATP7A and ATP7B, Ccc2p, serves a similar function. Ccc $2 p$ is required for incorporation of copper into the caeruloplasmin homologue Fet3p, a ferrireductase enabling growth of yeast under iron-deficient conditions. ${ }^{103}$ Incorporation of copper into Fet $3 p$ takes places within the Golgi apparatus, where Ccc $2 p$ resides under basal culturing conditions. ${ }^{104}$ Expression of both ATP7A and ATP7B rescues the growth phenotype of $C c c 2$ knockout yeast on iron-deficient media, making this an excellent model to study coppertransporting, ATPase-dependent cuproenzyme biosynthesis. $^{105} 106$ Using this Ccc2 knockout complementation 
assay, effects of WD-causing and MD-causing mutations on translocation of copper into the trans-Golgi network (TGN) lumen and subsequent incorporation of copper in cuproenzymes can be determined. This approach has been undertaken by several investigators, and indicates that multiple MDcausing and WD-causing mutations diminish or even completely abrogate the ability of ATP7A or ATP7B to rescue Fet3p biosynthesis or the Ccc2 knockout growth phenotype (tables 2 and 3). Taken together, these observations imply that ATP7A and ATP7B are critical for both proper delivery of copper to the TGN and subsequent cuproenzyme biosynthesis, and that mutations in ATP7A and ATP7B that perturb this process account for many of the clinical symptoms of MD and WD (table 1).

\section{Molecular mechanisms of ATP7A and ATP7B function and the effects of disease-causing mutations}

ATP7A and ATP7B exert their functions in copper transport through a variety of interdependent mechanisms and regulatory events. These include catalytic ATPase activity, copperdependent trafficking, post-translational modifications and protein-protein interactions. In recent years, extensive efforts have been undertaken to dissect and characterise these mechanisms, which will be discussed in this section in the context of the pathophysiology of MD and WD. As explained below, these mechanisms are highly interdependent, and specific MD-causing or WD-causing mutations can exert effects on multiple levels. Therefore, care should be taken in the interpretation of how such effects relate to the pathogenesis of MD and WD.

\section{ATPase catalytic cycle}

The ion translocation cycle by P-type ATPases is believed to occur through a general cycling model involving several discrete stages in which ATP hydrolysis drives translocation of the target ion (schematically depicted in fig 1). ${ }^{107}$ These stages are: (i) binding of the target ion, (ii) binding of ATP to the nucleotide-binding (N)-domain, (iii) ATP hydrolysis and phosphorylation of the phosphorylation (P)-domain, (iv) translocation of the target ion, and $(\mathrm{V})$ dephosphorylation of the P-domain by the actuator (A)-domain.

This model suggests that copper plays a key regulatory role in the catalytic cycle of ATP7A and ATP7B. ATP7A and ATP7B contain a number of putative copper-binding sites, of which the amino terminal MBSs are the best characterised. ${ }^{108} 109$ The amino terminal tail containing these MBSs interacts with the $\mathrm{N}$-domain of ATP7B, leading to inhibition of ATP binding. ${ }^{110}$ This interaction is inhibited by copper, providing a potential mechanism for copper-regulated availability of the $\mathrm{N}$-domain to bind ATP. ${ }^{110}$ Consistent with this hypothesis, both ATP hydrolysis and formation of the acylphosphate intermediate (step (3) in the model) are also dependent on copper. ${ }^{98}{ }^{111-114}$ The effect of copper on acylphosphate intermediate formation is cooperative, suggesting that the six amino terminal MBSs have a regulatory role in the formation of the acylphosphate intermediate. $^{98112113}$ Indeed, MBSs 5 and 6 are required for the cooperative effect of copper on acylphosphate intermediate formation. $^{112}$ However, mutation of all six amino terminal MBSs only mildly affects the rate and extent of catalytic phosphorylation of ATP7A, raising the possibility that other copper binding sites, such as the conserved intramembranous

Table 2 Effects of MD-causing missense mutations on function and regulation of ATP7A

\begin{tabular}{|c|c|c|c|c|c|}
\hline Mutation & Cuproenzyme biosynthesis & $\begin{array}{l}\text { Catalytic ATPase } \\
\text { activity }\end{array}$ & Localisation & $\begin{array}{l}\text { Post-translational } \\
\text { modifications }\end{array}$ & $\begin{array}{l}\text { Protein-protein } \\
\text { interactions }\end{array}$ \\
\hline A629P & $\begin{array}{l}\text { Reduced rescue } \Delta C c c 2 \\
\text { yeast }^{106}\end{array}$ & & & & \\
\hline S637L & $\begin{array}{l}\text { Reduced rescue } \Delta C c c 2 \\
\text { yeast }^{205}\end{array}$ & & & & \\
\hline $\mathrm{R} 844 \mathrm{H}$ & & & $\begin{array}{l}\text { No signal observed, protein absent in patient } \\
\text { fibroblasts }^{258}\end{array}$ & & \\
\hline G860V & & & $\begin{array}{l}\text { No signal observed, protein absent in patient } \\
\text { fibroblasts }^{258}\end{array}$ & & \\
\hline L873R & No rescue $\Delta C c c 2$ yeast ${ }^{114}$ & $\begin{array}{l}\text { Increased formation } \\
\text { of acylphosphate } \\
\text { intermediate }\end{array}$ & $\begin{array}{l}\text { Cell periphery and plasma membrane, }{ }^{114} \\
\text { no copper response }\end{array}$ & & \\
\hline G876R & & & $\begin{array}{l}\text { No signal observed, protein absent in patient } \\
\text { fibroblasts }^{258}\end{array}$ & & \\
\hline Q924R & & & Partial in cell periphery ${ }^{258}$ & & \\
\hline C1000R & No tyrosinase activity ${ }^{142}$ & & Normal, TGN, ${ }^{114258}$ no copper response ${ }^{114}$ & & \\
\hline A1007V & & & Normal, TGN ${ }^{258}$ & & \\
\hline G1015D & & & Normal, TGN ${ }^{258}$ & & \\
\hline G1019D & $\begin{array}{l}\text { Reduced rescue } \Delta C c c 2 \\
\text { yeast }^{106}\end{array}$ & & $\begin{array}{l}\text { Partial ER mislocalisation, }{ }^{146} \text { copper response } \\
\text { presentt }^{146}\end{array}$ & $\begin{array}{l}\text { Impaired } \\
\text { glycosylation }^{146}\end{array}$ & \\
\hline D1044G & & & Normal, TGN ${ }^{258}$ & & \\
\hline $\mathrm{K} 1282 \mathrm{E}$ & & & Normal, TGN ${ }^{258}$ & & \\
\hline G1300E & & & Normal, TGN ${ }^{258}$ & & \\
\hline G1302V & & & Partial in cell periphery ${ }^{258}$ & & \\
\hline N1304S & $\begin{array}{l}\text { Reduced rescue } \Delta C c c 2 \\
\text { yeast }^{259}\end{array}$ & & & & \\
\hline N1304K & & & Normal, TGN ${ }^{258}$ & & \\
\hline D1305A & & & Normal, TGN ${ }^{258}$ & & \\
\hline G1315R & & & Normal, TGN ${ }^{258}$ & & \\
\hline A1325V & & & $\begin{array}{l}\text { No signal observed, protein absent in patient } \\
\text { fibroblasts }^{258}\end{array}$ & & \\
\hline A1362D & $\begin{array}{l}\text { Reduced rescue } \Delta C c c 2 \\
\text { yeast }^{205}\end{array}$ & & & & \\
\hline $\mathrm{A} 1362 \mathrm{~V}$ & & & Normal, TGN, no copper response ${ }^{141}$ & & \\
\hline G1369R & & & $\begin{array}{l}\text { No signal observed, protein absent in patient } \\
\text { fibroblasts }^{258}\end{array}$ & & \\
\hline S1397F & & & Normal, TGN ${ }^{258}$ & & \\
\hline
\end{tabular}

ER, endoplasmic reticulum; TGN, trans-Golgi network. 
Table 3 Effects of WD-causing missense mutations on function and regulation of ATP7B

\begin{tabular}{|c|c|c|c|c|c|}
\hline Mutation: & $\begin{array}{l}\text { Cuproenzyme } \\
\text { biosynthesis }\end{array}$ & Catalytic ATPase activity & Localisation & $\begin{array}{l}\text { Post-translational } \\
\text { modifications }\end{array}$ & Protein-protein interactions \\
\hline G85V & & & Extensive ER mislocalisation ${ }^{149}$ & & $\begin{array}{l}\text { Decreased interaction with } \\
\text { ATOX } 1^{176} \\
\text { Increased interaction with } \\
\text { COMMDI }{ }^{149}\end{array}$ \\
\hline L492S & & & & & $\begin{array}{l}\text { Decreased interaction with } \\
\text { ATOX } 1^{176} \\
\text { Increased interaction with } \\
\text { COMMD1 } 1^{149}\end{array}$ \\
\hline G591D & & & Extensive ER mislocalisation ${ }^{149}$ & $\begin{array}{l}\text { Absence of copper- } \\
\text { induced } \\
\text { phosphorylation }{ }^{152}\end{array}$ & $\begin{array}{l}\text { Decreased interaction with } \\
\text { ATOX } 1^{176} \\
\text { Increased interaction with } \\
\text { COMMD1 } 1^{149}\end{array}$ \\
\hline A604P & & & & & $\begin{array}{l}\text { Increased interaction with } \\
\text { COMMD1 }\end{array}$ \\
\hline R616W & & & Normal, TGN ${ }^{126}$ & & \\
\hline G710S & & & Normal, TGN ${ }^{126}$ & & \\
\hline P760L & & & Normal, TGN ${ }^{126}$ & & \\
\hline $\mathrm{D} 765 \mathrm{~N}$ & $\begin{array}{l}\text { Normal rescue } \Delta C c c 2 \\
\text { yeast }^{143}\end{array}$ & & $\begin{array}{l}\text { Partial ER mislocalisation }{ }^{126} 127 \\
\text { Reduced copper response }\end{array}$ & & \\
\hline$M 769 \mathrm{~V}$ & $\begin{array}{l}\text { Normal rescue } \Delta C c c 2 \\
\text { yeast }^{133}\end{array}$ & & $\begin{array}{l}\text { Normal, TGN } \\
\text { Copper response unaffected }{ }^{127}\end{array}$ & & \\
\hline L776V & $\begin{array}{l}\text { Normal rescue } \Delta C c c 2 \\
\text { yeast }^{133}\end{array}$ & & $\begin{array}{l}\text { Partial ER mislocalisation }{ }^{127} \\
\text { Reduced copper response }^{127}\end{array}$ & & \\
\hline R778Q & $\begin{array}{l}\text { Reduced rescue } \Delta C c c 2 \\
\text { yeast }^{1 / 3}\end{array}$ & & & & \\
\hline $\mathrm{R} 778 \mathrm{~L}$ & 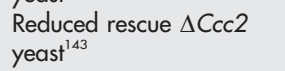 & & $\begin{array}{l}\text { Extensive ER mislocalisation }{ }^{127} \\
\text { Copper response absent }^{127}\end{array}$ & & \\
\hline W779X & & & $\begin{array}{l}\text { Cytoplasmic clusters }{ }^{126} \\
\text { Copper response absent }{ }^{126}\end{array}$ & & \\
\hline $\begin{array}{l}\text { G943S } \\
\text { R969Q }\end{array}$ & $\begin{array}{l}\text { Normal rescue } \Delta C c c 2 \\
\text { yeast }^{1 / 3}\end{array}$ & & $\begin{array}{l}\text { Normal, TGN }{ }^{127} \\
\text { Copper response absent }{ }^{127} \\
\text { Normal, TGN }\end{array}$ & & \\
\hline $\begin{array}{l}\text { T997M } \\
\text { V995A }\end{array}$ & $\begin{array}{l}\text { No rescue } \Delta C c c 2 \text { yeast }^{143} \\
\text { Normal rescue } \Delta C c c 2 \\
\text { yeast }^{143}\end{array}$ & & & & \\
\hline P992L & $\begin{array}{l}\text { Reduced rescue } \Delta C c c 2 \\
\text { yeast }^{143}\end{array}$ & & Normal, TGN ${ }^{126}$ & & \\
\hline $\begin{array}{l}\text { E1064A } \\
\text { H1069Q }\end{array}$ & 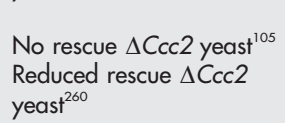 & $\begin{array}{l}\text { Absence of ATP binding }{ }^{117} \\
\text { Absence of ATP binding, } \\
\text { Absence of ATP hydrolysis } \\
\text { activity }^{214}\end{array}$ & $\begin{array}{l}\text { Extensive ER mislocalisation, }{ }^{126} 148 \\
\text { mislocalisation to aggrosomes }\end{array}$ & & \\
\hline $\mathrm{R} 1115 \mathrm{H}$ & & $\begin{array}{l}\text { Slightly decreased ATP } \\
\text { binding }\end{array}$ & & & \\
\hline N1270S & & $\begin{array}{l}\text { Reduced ATP hydrolysis } \\
\text { activity } 14\end{array}$ & $\begin{array}{l}\text { Normal, TGN } \\
\text { Normal, endosome }{ }^{144}\end{array}$ & & \\
\hline
\end{tabular}

ER, endoplasmic reticulum; TGN, trans-Golgi network.

CPC motif, play an important role in the regulation of this process. ${ }^{11}$

The next steps in the model predict that copper translocation by ATP7A and ATP7B is dependent on ATP binding and hydrolysis. Indeed, translocation of copper into membrane vesicles isolated from rat liver, and in vitro copper translocation activities of ATP7A and ATP7B, are ATP-dependent. ${ }^{96-98} 115116$ Using purified recombinant protein fragments, ATP binding to both the $\mathrm{N}$-domain and P-domain of ATP7B has been found. ${ }^{110117118}$ Molecular modelling analysis supports this experimental observation. ${ }^{119}$ The exact binding site for ATP in the $\mathrm{N}$-domain has not yet been identified, but analysis of the solution structure of the N-domain of ATP7B has implicated a number of residues in this process, including H1069, G1099, Gl101, Il102, G1149 and N1150. ${ }^{118}$ Interestingly, Hl069, G1099, G1101 and I1102 are all residues found mutated in WD, and H1069Q represents the most frequent WD-causing mutation in Europe and North America. ${ }^{59}$ Consistent with a role for this residue in ATP binding, the H1069Q mutation results in almost complete absence of ATP binding to ATP7B. ${ }^{117}$ However, within the $\mathrm{N}$-domain, $>40$ different WD-causing mutations have been reported, indicating that more residues might be involved in either direct ATP binding or coordination. ${ }^{59}$ This possibility is supported by experiments showing that the WDcausing E1064A mutation results in complete absence of ATP binding to the $\mathrm{N}$-domain of ATP7B. ${ }^{117}$

Molecular modelling analysis suggests that after initial ATP binding to the $\mathrm{N}$-domain of ATP7B, conformational changes take place that bring the ATP binding site within the N-domain in close proximity to the P-domain. ${ }^{19}$ This could potentially promote ATP binding and phosphorylation of the P-domain, the third step in the catalytic cycle model. ${ }^{119}$ ATP binding in the P-domain of ATP7B has been suggested to take place in the vicinity of D1027. ${ }^{119}$ This residue is part of the DKTG motif, which is highly conserved in all P-type ATPases, and is presumed to be the target of phosphorylation by the $\gamma$ phosphate of ATP. ${ }^{107}$ Mutation of this aspartic acid residue in either ATP7A or ATP7B completely prevents formation of an acylphosphate intermediate, thereby supporting this hypothesis. ${ }^{111} 113114$ Furthermore, this mutation in ATP7A is associated with a complete loss of copper translocation activity, the next step in the general model. ${ }^{111}$

Although copper translocation can be measured using isolated membrane vesicles from cells expressing ATP7A or ATP7B, or using purified ATP7A or ATP7B reconstituted in soybean asolectin liposomes, studies have yet to be performed 


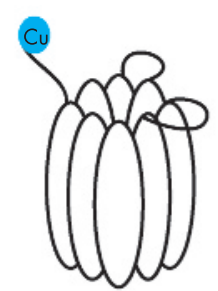

(i) Copper binding

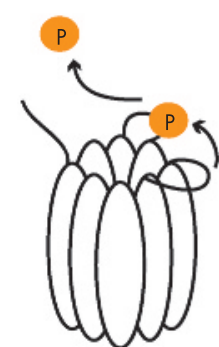

(v) Dephosphorylation by A-domain

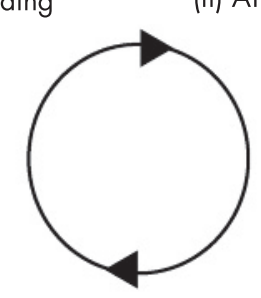

(ii) ATP binding to $\mathrm{N}$-domain

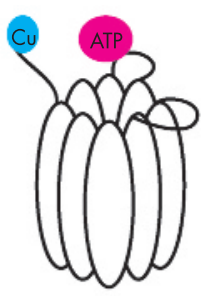

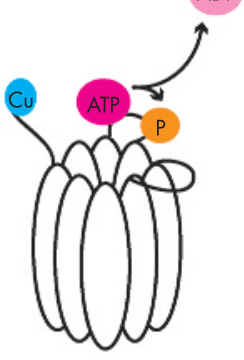

(iii) Phosphorylation of P-domain and release of ADP
Figure 1 Schematic representation of the general ATPase catalytic cycle. Copper translocation by ATP7A and ATP7B is believed to occur through a general cycling model involving several discrete stages. These stages include (i) binding of the target ion, (ii) binding of ATP to the N-domain, (iii) ATP hydrolysis and phosphorylation of the Pdomain, (iv) translocation of the target ion, and $(v)$ dephosphorylation of the P-domain by the A-domain.

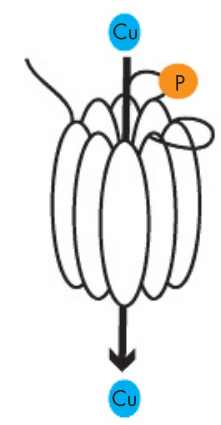

(iv) Copper translocation to characterise the effects of MD-causing and WD-causing mutations on this particular step in the cycling model. ${ }^{96} 98$ Furthermore, no studies have yet been performed to unravel the role of the intramembranous copper-binding CPC motif, which is presumed to play an essential role in this step. However, it has been shown that intact MBSs in the amino terminal region of ATP7A are required for proper translocation of ${ }^{64} \mathrm{Cu}$ in isolated membrane vesicles. ${ }^{120}$

Dephosphorylation of the aspartic acid residue is mediated by intrinsic phosphatase activity, in which the A-domain plays a key role. The signals that induce this phosphatase activity, and the mechanisms behind it, have not yet been elucidated, but an essential role has been ascribed to the conserved TGE motif. Mutation of this motif in ATP7A results in hyperphosphorylation of the protein. ${ }^{114}$ Although the TGE motif per se has not been reported to be mutated in $\mathrm{MD}$ or $\mathrm{WD}$, adjacent residues in ATP7A and ATP7B are known sites of MD-causing and WDcausing mutations..$^{59} 114$ In fact, the MD-causing L873R mutation, two amino acids upstream of the TGE motif, results in hyperphosphorylation of ATP7A. ${ }^{114}$

\section{Copper-dependent localisation of ATP7A and ATP7B} Under basal conditions, ATP7A and ATP7B are localised within the TGN (fig 2). ${ }^{105} 121122$ This localisation is consistent with their function in cuproenzyme biosynthesis, as several cuproenzymes are synthesised within the secretory pathway. Some controversy exists about the localisation of ATP7B, as it has also been suggested that this protein resides in an endosomal compartment. ${ }^{123} 124$ In addition, a smaller isoform of ATP7B exists, which has been localised to mitochondria. ${ }^{125}$ However, the current general agreement is that ATP7B is localised to the TGN, as this has been confirmed by several independent groups, including at ultrastructural resolution in human liver biopsies. ${ }^{105}{ }^{126-133}$
A key mechanism in the regulation of the copper export function of ATP7A and ATP7B became apparent from studies showing that the subcellular distribution of both proteins was sensitive to the concentration of copper to which the cell was exposed (fig 2, Box 3). In response to raised copper levels, ATP7A reversibly relocalises to a peripheral vesicular compartment and to the plasma membrane. ${ }^{122}{ }^{134}$ In polarised cells, and in intestinal tissue sections, ATP7A specifically localises towards the basolateral membrane upon copper exposure, consistent with its function in transferring copper across the intestinal barrier. ${ }^{135-138}$ ATP7A overexpressed in mouse liver tissue also localises at the hepatocyte basolateral membrane. ${ }^{139}$ Specific targeting of ATP7A to the basolateral membrane appears to be mediated through a putative PDZ binding motif present in the carboxy terminal tail of ATP7A. Deletion of this motif results in targeting of ATP7A to the apical membrane in response to raised copper levels. ${ }^{136}$ ATP7B undergoes a similar copper-induced relocalisation to a peripheral vesicular compartment. Although ATP7B has not been unequivocally detected at the plasma membrane of polarised cells, the idea that the transporter rapidly recycles between the peripheral vesicular compartment and the plasma membrane cannot be excluded. ${ }^{105}{ }^{140}$ In polarised hepatocytic cell lines, exposure to high copper concentrations results in localisation of ATP7B in the proximity of the apical vacuoles, a structure reminiscent of the bile canaliculus. ${ }^{46} 128130133140$ This observation is consistent with its proposed function in excretion of copper from the hepatocyte via the bile. Small amounts of ATP7B localised in the proximity of the bile canaliculus have also been detected in human liver tissues. ${ }^{130}$ Signals mediating the specific targeting of ATP7B towards the apical region seem to be present within the first 63 amino acids, a region that is not present in ATP7A. ${ }^{133}$ Taken together, these data indicate that differences in the trafficking destinations of ATP7A and ATP7B are not caused 


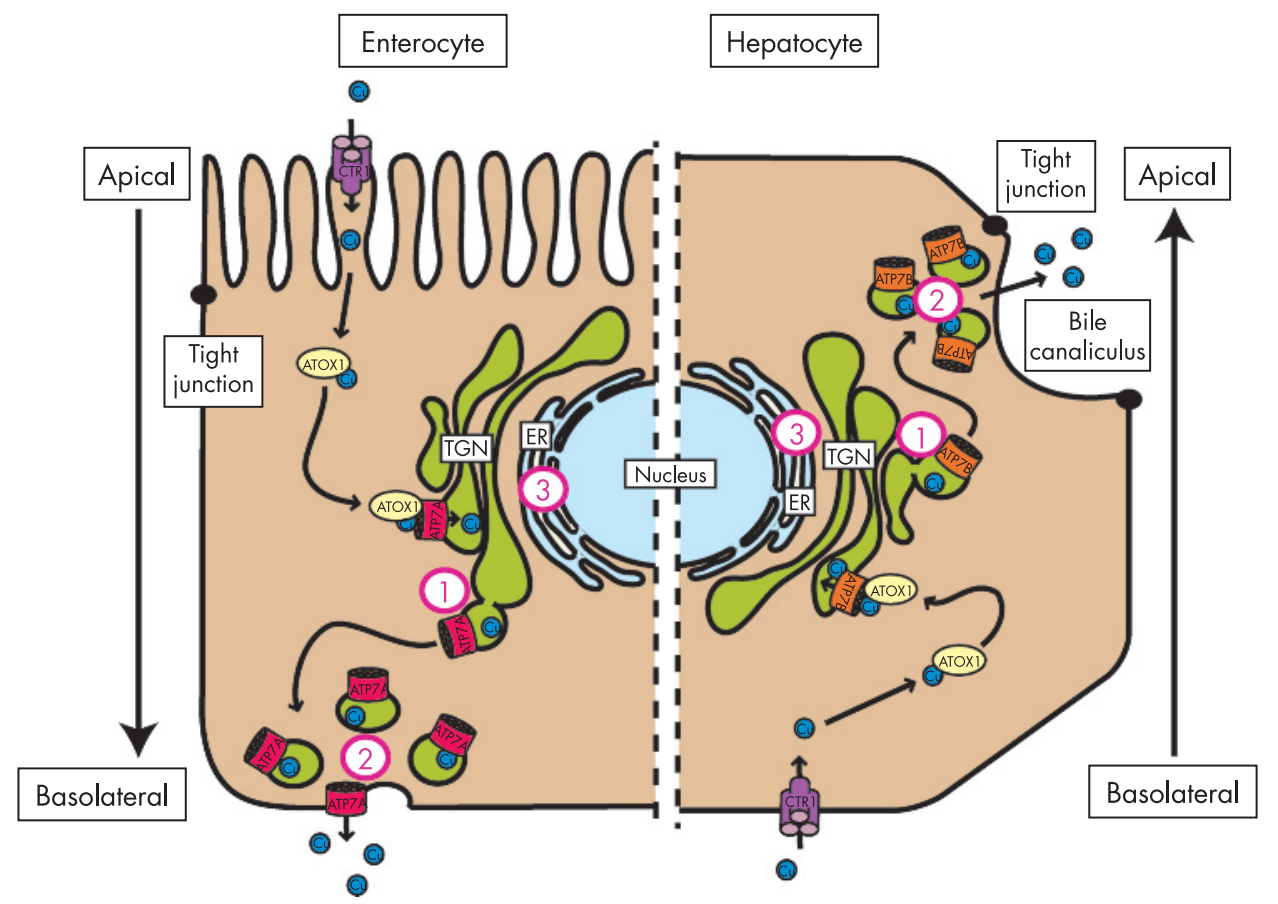

Figure 2 Schematic representation of copper-induced relocalisation of ATP7A and ATP7B. Left side depicts an enterocyte, and right side represents and hepatocyte. In both cells, copper enters through the copper transporter 1 (CTR1), and is then distributed via the copper chaperone ATOX1 to ATP7A or ATP7B residing in the TGN. After a rise in copper concentrations, ATP7A and ATP7B relocalise from the TGN to the cell periphery, and in the case of ATP7A also the plasma membrane, to facilitate excretion of copper. The main difference in these two copper transport pathways lies in the direction. In the enterocyte, ATP7A facilitates excretion of copper into the bloodstream at the basolateral side, whereas in the hepatocyte copper is excreted at the apical side into the bile. The numbers indicate localisation defects of ATP7A and ATP7B due to MDcausing and WD-causing mutations, respectively: (1) lack of copper responsiveness, resulting in constitutive localisation at the TGN, (2) constitutive localisation at the cell periphery, and (3) mislocalisation at the ER, presumably due to misfolding. by general cell-type specific differences in regulation of polarised membrane protein localisation, but rather are determined by intrinsic signals present in their amino acid sequences. The difference in the directionality of copperinduced relocalisation of ATP7A and ATP7B illustrates why two distinct, but very similar, copper export proteins are required to ensure proper copper uptake and excretion in higher organisms. In addition, this difference, resulting in distinct physiological functions of these homologous proteins in maintaining whole-body copper homeostasis, explains the opposed copper transport defects seen in MD and WD.

Several MD-causing and WD-causing mutations are associated with defects in copper-induced relocalisation of ATP7A and ATP7B respectively, suggesting that this is a key event that precedes cellular copper excretion by ATP7A and ATP7B. Therefore, such defects might possibly be associated with the pathogenesis of MD and WD. In general, MD-causing and WDcausing mutations can result in three types of localisation defects (tables 2 and 3, fig 3). The first type displays a normal steady-state localisation of the protein within the TGN, but responsiveness to copper is lost. ${ }^{114127141} 142$ One mutation of interest that has been shown to result in such a defect is the MD-causing C1000R mutation in ATP7A, which disrupts the putative copper-binding CPC motif, suggesting that in this case impaired copper binding causes the lack of copper-induced trafficking to the cell periphery. ${ }^{114}$ This type of localisation defect could potentially explain some of the biochemical symptoms seen in patients with MD or WD. For example,
Assessment throughout of general functions

\begin{tabular}{|c|c|}
\hline $\begin{array}{l}\text { Cellular copper transport } \\
\text { - Copper levels and copper retention } \\
\text { - Novel copper sensor tools }\end{array}$ & $\begin{array}{l}\text { Cuproenzyme biosynthesis } \\
\text { - Rescue of } \Delta C \operatorname{Cc} 2 \text { yeast }\end{array}$ \\
\hline \multicolumn{2}{|c|}{ Assessment throughout of functional mechanisms } \\
\hline $\begin{array}{l}\text { ATPase catalytic cycle } \\
\text { - ATP binding } \\
\text { - Formation of acylphosphate intermediate } \\
\text { - ATP catalysis }\end{array}$ & $\begin{array}{l}\text { Cellular localisation } \\
\text { - Steady-state localisation } \\
\text { - Copper dependent relocalisation }\end{array}$ \\
\hline $\begin{array}{l}\text { Post-translational modifications } \\
\text { - Glycosylation } \\
\text { - Phosphorylation }\end{array}$ & $\begin{array}{l}\text { Protein-protein interactions } \\
\text { - Interactions with ATOX } 1, C O M M D 1 \text {, } \\
\text { and other interacting partners }\end{array}$ \\
\hline
\end{tabular}

Characterisation of disease causing effects on function ATP7A and ATP7B
Figure 3 Proposed flow chart to analyse $M D$-causing and WD-causing mutations in ATP7A and ATP7B and to correlate the molecular defects to disease phenotype. MDcausing and WD-causing mutations can have profound effects on the functions of ATP7A and ATP7B. Thorough analysis of the functional and mechanistic defects resulting from these mutations will enhance understanding of MD and WD pathophysiology and the clinical heterogeneity seen in patients. 


\section{Box 1 Copper homeostasis}

Copper is taken up from the diet in enterocytes and subsequently effluxed to the liver through the portal vein. This step is blocked in MD and OHS (blue bar in fig 4). From the liver, copper is distributed to the general circulation to provide tissues with required copper. Excretion of the majority $(98 \%)$ of copper from the body is mediated by biliary export, indicating that the liver plays a central role in the regulation of body copper homeostasis. ${ }^{227}$ Copper excretion from the liver is defective in WD, ICC, ETIC and ICT (red bars in fig 4), resulting in accumulation of excess copper in the liver. To ensure copper homeostasis on the cellular level, refined mechanisms to regulate copper uptake, distribution and excretion have evolved. Copper import in the cell takes place via the copper transporters 1 and 2.102228229 After uptake, distribution of intracellular copper is facilitated by a group of proteins called copper chaperones, which function to deliver free copper to its sites of utilisation. Several human copper chaperones have been described; CCS delivers copper to SOD1 in the cytosol and mitochondria, ${ }^{230} 231$ COX 17 delivers copper to the cytochrome $C$ oxidase complex in mitochondria, ${ }^{232}{ }^{233}$ and ATOXI delivers copper to the copper-transporting ATPases ATP7A and ATP7B in the trans-Golgi complex. ${ }^{158} 159$ These copper-transporting ATPases play an essential role in the export of copper from the cell. Dysfunction of these proteins underlies the development of MD, OHS and WD, and forms the topic of this review.

although the G943S mutation in ATP7B prohibits copperinduced trafficking of ATP7B, this mutation still permits cuproenzyme biosynthesis in the $\Delta C c c 2$ complementation assay. ${ }^{127}{ }^{143}$ Although this correlation does not exist for all mutations causing this type of localisation defect, it could explain the normal caeruloplasmin production found in some patients with WD. Unfortunately, serum caeruloplasmin levels have only been described for one patient who was compound heterozygous for the G943S mutation, and this was indeed found to be within normal range. ${ }^{127}$ Although this type of localisation defect might still permit cuproenzyme biosynthesis in $\mathrm{MD}$, resulting in alleviation of the clinical phenotype, this might not always be obvious in patients, owing to an impairment in copper translocation across the mucosal barrier. More likely, this type of localisation defect could allow for the beneficial effects of copper replacement therapy in these patients. The second type of localisation defects is on the opposite side of the spectrum. Several MD-causing and WDcausing mutations result in constitutive peripheral localisation of ATP7A or ATP7B, respectively. ${ }^{114}{ }^{126}{ }^{141}$ Of interest is the MDcausing L873R mutation in ATP7A, targeting a residue located adjacent to the conserved TGE motif. In this case, a constitutively peripheral localisation of ATP7A as a result of this mutation has been associated with hyperphosphorylation of ATP7A, suggesting that copper-induced relocalisation is dependent on the ATPase catalytic cycle (further discussed in Box 3). ${ }^{114}$ The third type of localisation defect is probably the most common and clinically important. MD-causing and WD-causing mutations result in mislocalisation, or possibly retention, of ATP7A and ATP7B within the endoplasmic reticulum. ${ }^{126} 127140$ 144-149 Strikingly, this defect has been found for the two most common WD-causing mutations, H1069Q and R778L. ${ }^{126}{ }^{127}{ }^{148}$ Some controversy exists about the localisation of the $\mathrm{H1069Q}$ variant, as this has also been reported to localise to aggresomes. ${ }^{144}$ ER mislocalisation of proteins is often due to misfolding and associated with proteasomal degradation. ${ }^{150} \mathrm{~A}$

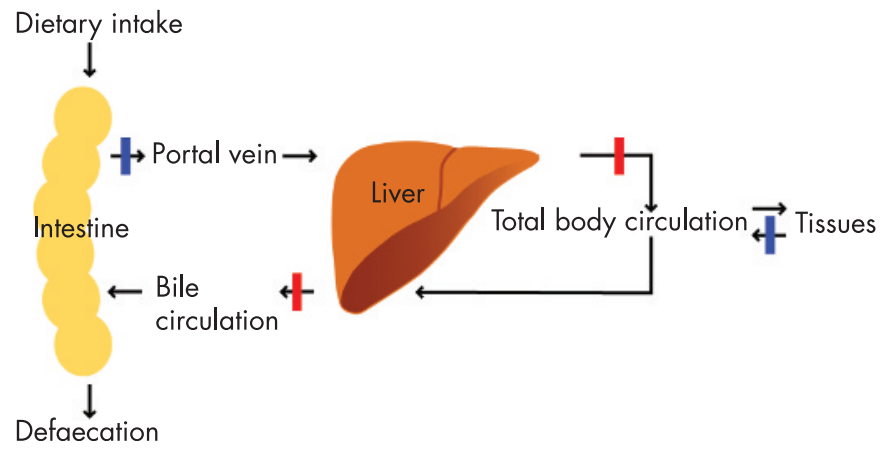

Figure 4 Schematic representation of the physiology of copper homeostasis.

well-known example of this process in human disease development is the ER-associated degradation of the $\Delta \mathrm{F} 508$ CFTR mutant in cystic fibrosis. ${ }^{151}$ In analogy, the H1069Q mutation in ATP7B indeed results in an increased proteolysis rate ${ }^{144} 148$ Whether the increased proteolysis resulting from the H1069Q mutation is due to defects in the conformation of ATP7B remains unclear, but the solution structure of the Ndomain of ATP7B containing the H1069Q mutation shows no folding defects. ${ }^{118}$

\section{Post-translational modifications}

Most efforts in investigating putative post-translational modifications of ATP7A and ATP7B have focused on the formation of the acylphosphate intermediate during the catalytic cycle. However, recent studies have led authors to suggest that both ATP7A and ATP7B are subject to basal and copper-induced phosphorylation that is distinct from the formation of the acylphosphate intermediate. ${ }^{152}{ }^{153}$ Both basal and copperinduced phosphorylation could still be observed with a catalytically inactive mutant of ATP7B, indicating that these types of phosphorylation are indeed distinct from the formation of the acylphosphate intermediate, and that specific kinases are required. ${ }^{154}$ Copper-induced phosphorylation of ATP7B is partially inhibited by an inhibitor of casein kinase II. ${ }^{152}$ Phosphoamino acid analysis indicates that both ATP7A and ATP7B are phosphorylated on serine residues. ${ }^{153}{ }^{155}$ In addition to phosphorylation, modification of ATP7A with N-linked glycan chains has also been found. ${ }^{121}$ Although little is known about the functional effects of ATP7A glycosylation, it is interesting that this type of modification is probably specific to ATP7A, as the amino acid sequence of ATP7B does not contain any consensus glycosylation sites at relevant extracytoplasmic domains.

Taken together, studies on post-translational modifications of ATP7A and ATP7B are still in their initial phases, but could shed important new light on our understanding of the regulation of these copper-transporting ATPases. The importance of these modifications is emphasised by the absence of copper-induced phosphorylation of ATP7B due to the WDcausing G591D mutation, and absence of ATP7A glycosylation, due to the MD-causing G1019D mutation (tables 1, 2). ${ }^{146} 152$

\section{Protein-protein interactions}

Protein-protein interactions form an essential mechanism through which many proteins exert their functions. Mapping of the protein-protein interactome provides a valuable framework for elucidating the functional organisation of the human proteome, and consequently to understanding of the molecular pathology of human disease. ${ }^{156}$ In recent years, significant process has been made in unravelling the ATP7A and ATP7B interactome (Box 4). In the following, we elaborate on two of 


\section{Box 2 Structure of copper-transporting ATPases}

ATP7A and ATP7B are highly homologous and both belong to the heavy metal-transporting $P(1 B)$-type ATPases. The basic topology of ATP7A and ATP7B is depicted in figure 5. The polypeptide sequences of ATP7A and ATP7B are $54 \%$ identical, however two sequence inserts are present in ATP7A that are not present in ATP7B (the position of these sequences are marked with an arrow). Several conserved motifs are present in both ATP7A and ATP7B that are characteristic for the P-type ATPase protein family. ${ }^{107}$ These motifs are required for ATP catalysis and include the nucleotide binding domain ( $\mathrm{N}$-domain; depicted in blue), the phosphorylation domain (P-domain; depicted in green) and the actuator domain (A-domain; depicted in red). Highly conserved signature residues are present in these motifs; SEHPL in the N-domain, DKTG in the Pdomain, and TGE in the A-domain. The specific functions of these domains are discussed in the text. Within the amino terminal tail, six MBSs; depicted in purple) are present, each containing the core sequence $\mathrm{MxC} \times \mathrm{xC}$. These MBSs bind $\mathrm{Cu}(\mathrm{l})$ in a stoichiometry of one atom of Cu(I) per MBS. ${ }^{108} 109$ Structural analysis of separate MBSs of ATP7A or ATP7B has shown a conserved $\beta \alpha \beta \beta \alpha \beta$ folding structure. ${ }^{234-240}$ The sequence and structure of these MBSs are highly conserved in evolution and to other proteins, such as the copper chaperone ATOX $1 .{ }^{28}$ These amino-terminal MBSs in ATP7A and ATP7B are required for several aspects of their function, including copper translocation, incorporation of copper in cuproenzymes, ATPase activity, localisation and trafficking, and protein-protein interactions. $106111112114120131136162168171241-243$ Strikingly, however, bacterial and yeast orthologues of ATP7A and ATP7B only contain one or two MBSs, indicating that the six MBSs in ATP7A and ATP7B might be partially redundant. In general, it is believed that P-type ATPases contain binding sites for their substrate ion within their transmembrane regions to facilitate transfer of these ions across the membrane barrier. ${ }^{107}$ Transmembrane domain 6 contains a highly conserved CPC motif (depicted in purple) that is characteristic for heavy metal transporting P-type ATPases. ${ }^{244} 245$ Peptides containing this motif have been shown to bind copper, indicating that the CPC motif could indeed be involved in the actual transfer of copper across the membrane. ${ }^{240}$

the interacting partners of ATP7A and ATP7B that can be directly linked to the development of copper homeostasis disorders.

Owing to its toxic potential, concentrations of free copper inside the cell are extremely low. In fact, it has been estimated that yeast maintains a concentration of $<1$ free copper ion per cell. ${ }^{157}$ As a consequence of such low free copper concentrations, donor proteins are required for the delivery of substrate copper to copper-transporting ATPases. Originally isolated as a suppressor of oxidative toxicity in yeast, Atxlp (and its human orthologue ATOX1) was shown to be required for coppertransporting ATPase-mediated cuproenzyme biosynthesis ${ }^{158-160}$ Subsequently, it was demonstrated that ATOXI interacts with both ATP7A and ATP7B. ${ }^{161}{ }^{162}$ This interaction is conserved in yeast and bacteria, illustrating its importance. ${ }^{163-166} \mathrm{An}$ MxCxxC-containing MBS, homologous to those in ATP7A and ATP7B, is present in ATOX1, through which it has been shown to bind copper. ${ }^{163} 167$ The interaction of ATOX1 with ATP7A or ATP7B is copper-dependent and requires intact MBSs of both ATOX1 and ATP7A or ATP7B. ${ }^{161-163}{ }^{168-171}$ These data suggest that ATOX1 delivers copper to ATP7A and ATP7B, which in fact has been demonstrated in vitro. ${ }^{172-175}$ Atoxl knockout mice display a

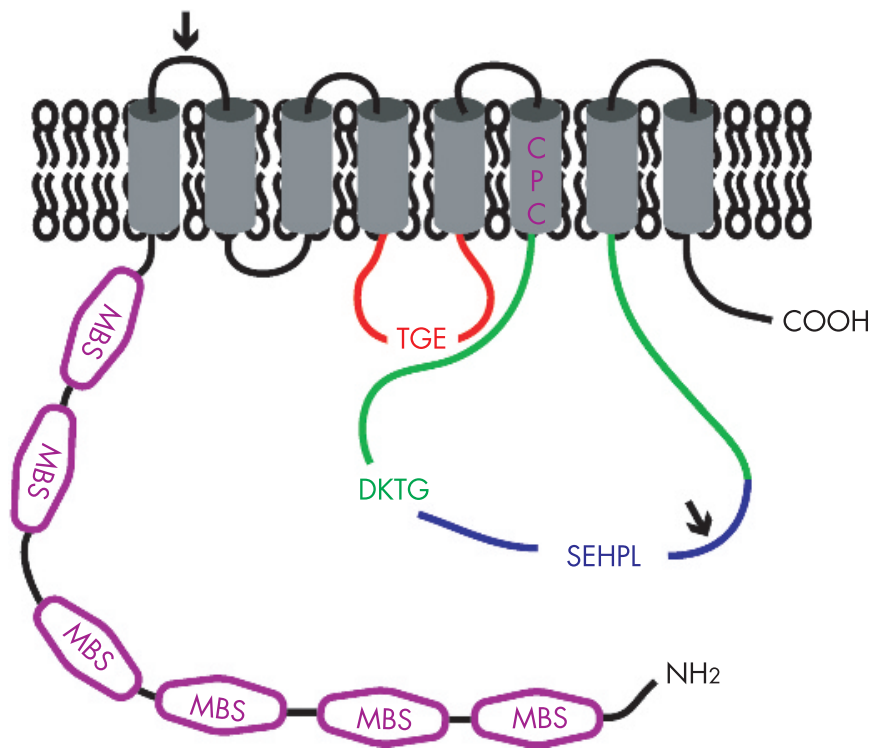

Figure 5 Schematic representation of the topology of ATP7A and ATP7B.

phenotype similar to that seen in patients with MD including symptoms such as growth failure, skin laxity, hypopigmentation and seizures. ${ }^{160}$ Consistent with a copper excretion defect caused by defective copper delivery to ATP7A, cultured fibroblasts isolated from Atoxl knockout mice exhibit an increase in copper retention and content. ${ }^{160}{ }^{176}$ A timedependent and dose-dependent impairment of copper-induced relocalisation of ATP7A has also been found in these cells. ${ }^{176}$ One possible defect underlying the development of MD and WD could thus be an impairment of the interaction of ATOXl with ATP7A or ATP7B respectively. Indeed, several mutations in the amino terminal tail of ATP7B prevent its interaction with ATOX1. ${ }^{161}$ Two of these mutations, G85V and G591D, affect highly conserved glycine residues in the proximity of the MxCxxC core sequence in MBS 1 and 6 respectively, indicating an important role for this conserved residue in coordination of the ATOX1-ATP7B interaction. ${ }^{161}$ However, these mutations also result in mislocalisation of ATP7B to the ER, which might also underlie the loss of interaction of ATP7B with ATOX1 caused by these mutations. ${ }^{149}$

Recent studies have shown that COMMDl, the protein defective in CT, interacts with ATP7B and that this interaction is mediated by the amino terminal tail of ATP7B. ${ }^{177}$ Transient knock-down of COMMD1 in HEK293 cells results in increased cellular copper levels. ${ }^{178}$ These data suggest that COMMDI and ATP7B cooperate in the excretion of copper from the hepatocyte, and that absence of the interaction between these proteins underlies the pathophysiology of CT in Bedlington terriers with the COMMDI deletion. Strikingly, COMMDl also interacts with ATP7A, indicating that COMMDI has a role in general copper homeostasis that is not restricted to the liver (de Bie et al., unpublished observation). COMMDl has also recently been implicated in several other cellular processes, including the nuclear factor (NF)- $\mathrm{KB}$ and HIFl signalling pathways. ${ }^{85}$ 179-184 In these two pathways, COMMDl is thought to exert its regulatory role by regulating the proteasomal degradation of key components of these pathways. ${ }^{179} 181182185$ With this in mind, COMMDl might also regulate the proteasomal degradation of ATP7A and ATP7B, thus regulating copper homeostasis. Other examples exist in which cuproenzymes or copper transport proteins, such as the copper chaperone for superoxide dismutase 1 (CCS) and hephaestin, are regulated by means of proteasomal degradation in response to altering copper levels. ${ }^{186} 187$ The WD-causing 
Box 3 Signals and mechanisms mediating copperinduced trafficking of ATP7A and ATP7B

Signals and mechanisms underlying the localisation and copper-induced trafficking of ATP7A and ATP7B have been the focus of many studies. Steady-state TGN localisation of ATP7A has been shown to be mediated by a putative TGNtargeting signal within transmembrane domain $3 .{ }^{147}$ Although transmembrane region 3 of ATP7B shows a high degree of conservation with that of ATP7A, it is unknown if it serves the same TGN-targeting function. Copper-induced relocalisation of ATP7A and ATP7B appears to be initiated by direct binding of copper to ATP7A and ATP7B. Deletion or mutation of all amino terminal MBS or the putative copper-binding CPC sequence results in an inability to induce the copper-dependent relocalisation. ${ }^{114} 131136242243$ Strikingly, however, the presence of only one intact amino terminal MBS is sufficient for normal copper-induced relocalisation. ${ }^{131} 242243246247$ This observation indicates that the six different MBSs have redundant functions, at least in copper-induced relocalisation of ATP7A and ATP7B. However, some studies have attributed a particularly important role to MBSs 5 and 6 for copper-induced relocalisation, suggesting that these specific MBSs serve a different function from the others. ${ }^{131} 242246 \mathrm{In}$ addition to copper binding, phosphorylation status plays an important role in the regulation of trafficking of ATP7A and ATP7B. Mutation of the aspartic acid residue in the DKTG motif, which prohibits the formation of an acylphosphate intermediate, abolishes copper-induced trafficking of ATP7A and ATP7B from the TGN to the cell periphery. ${ }^{114} 140$ Conversely, hyperphosphorylation of ATP7A or ATP7B induced by mutation of the TGE motif results in a constitutive peripheral localisation. ${ }^{114} \mathrm{~A}$ combination of mutations of the TGE motif, the six amino terminal MBSs and the CPC motif in ATP7B also shows constitutive peripheral localisation. ${ }^{247}$ This fascinating observation can be explained in two ways. It is possible that other metal-binding sites are present in ATP7B through which relocalisation can be induced by copper. Alternatively, ATP7B constitutively cycles between the TGN and the cell periphery, and copper binding serves as a retention signal, inhibiting retrograde trafficking to the TGN. Retrograde trafficking of ATP7A from the plasma membrane back to the TGN requires a dileucine motif within the carboxyterminal tail. ${ }^{134} 248249$ Although this motif might serve as a classic clathrin-mediated endocytosis targeting motif, other mechanisms play a role in the internalisation of ATP7A from the plasma membrane. ${ }^{250} 251 \mathrm{~A}$ trileucine motif is present at the same position of ATP7B, and although ATP7B does not reach the plasma membrane, mutation of this motif also results in a constitutive peripheral localisation of ATP7B. ${ }^{140}$

These studies have provided valuable insights into the mechanisms behind copper-induced trafficking of ATP7A and ATP7B. One of the most important remaining questions is how exactly copper is exported from the cell after this event has occurred, and this should be the focus of future studies.

mutations G85V, L492S, G591D, and A604P result in increased binding of ATP7B to COMMD1, suggesting that disruption of this interaction could underlie the development of WD in some cases. ${ }^{19}$ The G85V and G591D mutations have also been associated with ER mislocalisation and increased degradation of ATP7B, supporting the hypothesis that COMMDl facilitates the degradation of ATP7B. ${ }^{149}$ Recently, 10 homologues of COMMDI that are characterised by a conserved domain have been described, and are also involved in regulation of $\mathrm{NF}-\kappa \mathrm{B}$ signalling. ${ }^{85}{ }^{184}$ It would be interesting to investigate if these homologues of COMMDl also have a functional role in copper homeostasis, possibly through interactions with ATP7B or ATP7A.

\section{Genotype-phenotype correlations in the development of MD and WD}

Proper characterisation of the defects in MD and WD is required to resolve the clinical heterogeneity that is seen in both disorders. Either environmental or genetic variations might underlie this clinical heterogeneity. For example, development of ICC, ETIC and ICT is associated with a high copper intake. ${ }^{56863}$ Although such correlation has not been found for WD, it is possible that high copper intake might exacerbate the symptoms, whereas dietary components having low copper but high zinc concentrations might have a beneficial effect. Genetic variations in genes other than ATP7A and ATP7B might modulate the clinical expression of $\mathrm{MD}$ and $\mathrm{WD}$. In various other disorders with a mendelian mode of inheritance, it has been shown that modifier genes can modulate penetrance, dominance modification, expressivity and pleiotrophy. ${ }^{188}$ This is exemplified by genetic modification of the severity and expressivity of cystic fibrosis by polymorphisms in various genes, including mannose-binding lectin and transforming growth factor $\beta$ (reviewed by Cutting ${ }^{189}$ and Boyle ${ }^{190}$ ). COMMD1 has been proposed as a modifier gene for the clinical presentation of WD, as heterozygosity for a silent missense mutation in COMMDl was found to be possibly associated with an earlier onset of the disorder in patients with known ATP7B mutations. ${ }^{80}$ In other cohorts of patients with WD, no association between variations in COMMDl and the clinical expression of WD was found. ${ }^{78} 81{ }^{82}$ However, these cohorts were not classified to include patients with WD with identical mutations in ATP7B, which should be performed to reliably assess the possible role of COMMDl as a modifier gene for the clinical presentation of WD. Variations genes coding for prion protein and apolipoprotein $\mathrm{E}$ have been proposed to modify the presentation of WD, although for the latter this has not been consistently found. ${ }^{191-194}$

Notwithstanding the role modifier genes and environmental factors play, it is evident from the functional data discussed above that different mutations in $A T P 7 A$ or $A T P 7 B$ can potentially result in different functional effects. Therefore, it appears likely that also the type of mutation, or the residue(s) affected, modulate the clinical expression of MD or WD. For example, functional redundancy among the six amino terminal MBSs explains the relatively low amount of MD-causing or WD-causing missense mutations within the amino terminal tails of ATP7A and ATP7B. In addition, it has recently been found that translation reinitiation after a deletion in the amino terminal coding region of the ATP7A transcript produces a truncated protein containing only the fifth and sixth MBSs. Interestingly, this truncated protein was still partially functional, and the patient in which this phenomenon was found displayed a remarkably mild MD phenotype. ${ }^{195}$ A suggestive correlation between the severity of the phenotype and the extent to which missense mutations impair the function of Atp7a was recently found in three types of Mottled mice. ${ }^{196}$

Many studies have focused on establishing genotypephenotype correlations in both MD and WD. Severe mutations such as nonsense and frameshift mutations causing insertions/ deletions are generally believed to completely disrupt protein function, and would therefore be expected to yield a more severe clinical phenotype. Indeed, for WD it has been shown that severe mutations lead to an earlier onset of the disease, but a correlation with the type of presentation (neurological vs. hepatic) has not been found. ${ }^{197-200}$ Similarly, it has been suggested that severe mutations in ATP7A result in classic MD, whereas mild MD is caused by mutations that still permit residual activity 


\section{Box 4 The ATP7A and ATP7B interactome}

Identification of protein-protein interactions is a powerful tool to understand protein function and how perturbation of protein function results in human disease. Over the past few years several interacting partners for ATP7A and ATP7B have been reported, resulting in a rapid elaboration of the ATP7A and ATP7B interactome (figure 6). ${ }^{177} 252-255$ The best characterised interacting partner of ATP7A and ATP7B is ATOX1. Through its role to deliver copper to ATP7A and ATP7B, ATOX1 plays an essential role in the function of ATP7A and ATP7B, which is further discussed in the text. However, additional proteins might be involved in the delivery of copper to ATP7A and ATP7B. Among these is glutaredoxin, which interacts with both ATP7A and ATP7B in a copper-dependent manner, and has been hypothesised to regulate copper binding by ATP7A and ATP7B. ${ }^{252}$ In addition, copper delivery to ATP7A and ATP7B might be regulated by the immunophillin FKBP52. This protein interacts with ATOX1 in a copper-dependent manner, and overexpression of FKBP52 results in increased cellular copper efflux. ${ }^{256}$ The exact mechanisms through which FKBP52 attenuates its role in the copper-excretion pathway need to be further characterised. COMMDI, the protein defective in $C T$, interacts with both ATP7A and ATP7B' ${ }^{149} 177$ (de Bie et al, unpublished observations). The function of these interactions remains to be characterised, but the phenotype resulting from absence of COMMDI in CT suggests that COMMDI and ATP7B cooperate to facilitate billiary copper excretion (further discussed in the text). Another recently identified interacting partner for ATP7A is AIPP1. ${ }^{255}$ This PDZ domain-containing protein binds to the carboxy terminal tail of ATP7A, where a putative PDZ binding motif is present. As this motif is required for targeting of ATP7A to the basolateral membrane, it has been suggested that AIPP1 has a regulatory role in the copperinduced trafficking of ATP7A. ${ }^{136} 255$ Through its amino terminal tail, ATP7B interacts with the dynactin subunit p62 in a copperdependent manner. ${ }^{253}$ As the dynactin protein complex is involved in membrane vesicle movement along microtubules, this interaction suggests that the p62 dynactin subunit facilitates copper-induced trafficking of ATP7B. ${ }^{257}$ Further identification and characterisation of novel interacting partners of ATP7A and ATP7B will also shed new light on previously unanticipated functions of these proteins, as evidenced by the recently observed interaction between ATP7B and a promyelocytic leukemia zinc finger protein (PLZF) isoform. Characterisation of the interaction between the PLZF isoform and ATP7B suggested that ATP7B attenuates activation of the ERK signaling pathway. ${ }^{254}$ Further investigation is needed to determine the implications of this observation.

of ATP7A. ${ }^{201}$ On the other hand, OHS is often associated with splice site mutations. Although these mutations are predicted to dramatically affect ATP7A mRNA splicing, expression of the normal transcript is often still detectable, indicating that minor amounts of normally spliced ATP7A expressed in these patients are sufficient to allow for an alleviation of the phenotype. ${ }^{18} 40202-$

${ }^{204}$ In addition, it was suggested in a recent case report that, in two brothers with MD carrying the same mutation in ATP7A, differences in severity of the disease correlated with the amount of ATP7A expressed. ${ }^{205}$

Genotype-phenotype correlation analyses for missense mutations are less clear. Approximately 30\% of all cases with MD result from de novo mutations, as a result of which mutations are often very rare, thus prohibiting proper genotypephenotype correlation analysis using large numbers of patients.

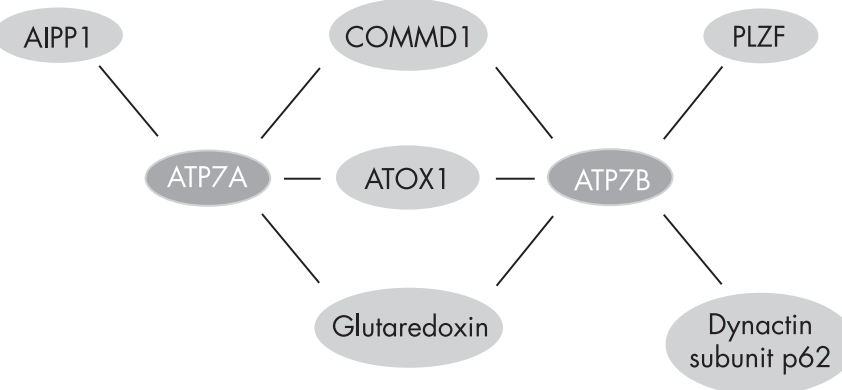

Figure 6 The ATP7A and ATP7B interactome.

Unfortunately, such studies in WD are also hampered by the large number of mutations detected; most mutations are very rare, and therefore most patients with WD are compound heterozygous. In a large number of studies, no genotypephenotype correlation could be found. As most of these studies relied on small patient cohorts, combining data from several independent studies in a meta-analysis could be useful to shed more clarity on this issue, as has been the case for the common H1069Q mutation. ${ }^{206}$ In several independent cohorts, a correlation between ATP7B H1069Q homozygosity and a neurological presentation of WD has been found..$^{206-211}$ In addition, this genotype has been associated with a significantly later age at onset. ${ }^{198} 1992062^{208-215}$ In several other studies, one or both of these observations could not be statistically confirmed. ${ }^{198} 207$ 212-220 However, a meta-analysis of all genetic studies before 2004 devoted to H1069Q genotype and phenotype indicated that overall, H1069Q homozygosity is indeed associated with a late neurological presentation of WD. ${ }^{206}$ A similar correlation with a later age at onset in WD has been found for patients homozygous for the R969Q mutation. ${ }^{199}$ In some cohorts, it seems that homozygosity for the R778L mutation correlates with an early, hepatic presentation of WD. ${ }^{221} 222$ It has been suggested that alternative splicing of ATP7B in the brain, resulting in absence of exon 8 (harbouring the R778 residue), underlies this suggested correlation. ${ }^{222}{ }^{223}$ However, here also, studies could not confirm the correlation of the homozygous R778L genotype with hepatic presentation, although a tendency towards this observation was sometimes present. ${ }^{224-226}$

\section{CONCLUSION}

Mutations in the structurally and functionally highly homologous copper-transporting ATPases ATP7A and ATP7B underlie both copper deficiency and overload diseases. Tremendous progress has been made in the characterisation of the function of these proteins, and how this is impaired in MD and WD. From the data presented in tables 2 and 3, it is evident that different mutations in ATP7A or ATP7B result in a variety of defects in the molecular functions of these proteins. Consistent with this notion, to some extent a correlation of the genotype with the heterogeneous phenotypes has been found in these disorders. However, it is also very likely that some of the different mutations in ATP7A or ATP7B result in overlapping functional impairments. This overlap could form a potential bias in genotype-phenotype correlation studies, in which correlations might be missed due to such an overlap in test and control patients. To overcome this potential bias, genotypephenotype correlations should be performed using patient groups classified primarily using the functional effects of the disease-causing mutations. This approach would also permit the performance of correlation studies with relatively mild or rare, mutations. At present, this approach is unfortunately not yet possible, as only a limited number of MD-causing or WD-associated variants of ATP7A and ATP7B have been 
functionally characterised (tables 2 and 3). Furthermore, a thorough characterisation of all molecular mechanisms that participate in the copper transport functions of ATP7A and ATP7B would be required, as these mechanisms are highly interdependent (as schematically suggested in fig 3). Such characterisation of mutations in ATP7A and ATP7B should be an important focus of future studies on the functional genetics of MD and WD, and will result in valuable insights into the molecular pathogenesis of MD and WD.

\section{ACKNOWLEDGEMENTS}

We thank members of the Leo Klomp and Cisca Wijmenga laboratories for helpful discussions. The work in these two laboratories is funded by the Netherlands Organization for Scientific Research (Zon-MW, grant 40-00812-98-03106), the Dutch Digestive Diseases Foundation (MLDS, grant WS 02-34), the Wilhelmina Children's Hospital (WKZ) Fund (grant 901-04-219). The authors declare they have no competing interests.

\section{Authors' affiliations}

P de Bie, P Muller, L W J Klomp, Laboratory of Metabolic and Endocrine Diseases, University Medical Center, Utrecht, The Netherlands

P de Bie, P Muller, C Wijmenga, Complex Genetics Section, DBGDepartment of Medical Genetics, University Medical Center, Utrecht, The Netherlands

C Wijmenga, Department of Genetics, University Medical Center, Groningen, The Netherlands

Competing interests: None declared.

\section{REFERENCES}

1 Culotta VC, Gitlin JD. Disorders of copper transport. In: Scriver CR, Beaudet AL, Sly WS, et al, eds. The metabolic and molecular bases of inherited disease. New York: McGraw-Hill, $2001 ; 2: 3105-26$.

2 Stohs SJ, Bagchi D. Oxidative mechanisms in the toxicity of metal ions. Free Radic Biol Med 1995; 18:321-36.

3 Menkes JH, Alter M, Steigleder GK, Weakley DR, Sung JH. A sex-linked recessive disorder with retardation of growth, peculiar hair, and focal cerebral and cerebellar degeneration. Pediatrics 1962;29:764-79.

4 Wilson SAK. Progressive lenticular degeneration: A familial nervous disease associated with cirrhosis of the liver. Brain 1912;34:295-509.

5 Tanner MS. Role of copper in Indian childhood cirrhosis. Am J Clin Nutr 1998:67(Suppl): 1074-81S

6 Muller T, Feichtinger H, Berger H, Muller W. Endemic Tyrolean infantile cirrhosis: an ecogenetic disorder. Lancet 1996;347:877-80.

7 Muller T, Muller W, Feichtinger H. Idiopathic copper toxicosis. Am J Clin Nutr 1998;67(Suppl): 1082-6S.

8 Scheinberg IH, Sternlieb I. Wilson disease and idiopathic copper toxicosis. Am J Clin Nutr 1996;63:842-5S

9 Danks DM, Campbell PE, Walker-Smith J, Stevens BJ, Gillespie JM, Blomfield J, Turner B. Menkes' kinky-hair syndrome. Lancet 1972;1:1100-2.

10 Tonnesen T, Kleijer WJ, Horn N. Incidence of Menkes disease. Hum Genet 1991:86:408-10.

11 Gu YH, Kodama H, Shiga K, Nakata S, Yanagawa Y, Ozawa H. A survey of Japanese patients with Menkes disease from 1990 to 2003: incidence and early signs before typical symptomatic onset, pointing the way to earlier diagnosis. $J$ Inherit Metab Dis 2005;28:473-8.

12 Danks DM. Disorders of Copper transport. In: Scriver CR, Beaudet AL, Sly WM, et al, eds. The metabolic and molecular basis of inherited disease. New York: McGraw-Hill, 1995:221 1-35.

13 Kaler SG. Metabolic and molecular bases of Menkes disease and occipital horn syndrome. Pediatr Dev Pathol 1998;1:85-98.

14 Mercer JF. Menkes syndrome and animal models. Am J Clin Nutr 1998;67(Suppl): 1022-8S.

15 Tumer Z, Horn N. Menkes disease: underlying genetic defect and new diagnostic possibilities. J Inherit Metab Dis 1998;21:604-12.

16 Procopis P, Camakaris J, Danks DM. A mild form of Menkes steely hair syndrome. J Pediatr 1981;98:97-9.

17 Danks DM. The mild form of Menkes disease: progress report on the original case. Am J Med Genet 1988;30:859-64.

18 Kaler SG, Gallo LK, Proud VK, Percy AK, Mark Y, Segal NA, Goldstein DS, Holmes CS, Gahl WA. Occipital horn syndrome and a mild Menkes phenotype associated with splice site mutations at the MNK locus. Nat Genet 1994;8:195-202.

19 Proud VK, Mussell HG, Kaler SG, Young DW, Percy AK. Distinctive Menkes disease variant with occipital horns: delineation of natural history and clinical phenotype. Am J Med Genet 1996;65:44-51

20 Kaler SG. Diagnosis and therapy of Menkes syndrome, a genetic form of copper deficiency. Am J Clin Nutr 1998;67(Suppl):1029-34S.
21 Sheela SR, Latha M, Liu P, Lem K, Kaler SG. Copper-replacement treatment for symptomatic Menkes disease: ethical considerations. Clin Genet 2005:68:278-83.

22 Sarkar B, Lingertat-Walsh K, Clarke JT. Copper-histidine therapy for Menkes disease. J Pediatr 1993;12:828-30.

23 Sarkar B, Kruck TPA. Copper-amino acids complexes in human serum. In: Peisach J, Aisen P, Blumberg WE, eds. The biochemistry of copper. New York: Academic Press, 1966:183-96.

24 Olivares JL, Bueno I, Gallati S, Ramos FJ. Late-onset treatment in Menkes disease: is there a correlation between genotype and response to therapy? Clin Genet 2006;69:363-6.

25 Chelly J, Tumer Z, Tonnesen T, Petterson A, Ishikawa-Brush Y, Tommerup N, Horn N, Monaco AP. Isolation of a candidate gene for Menkes disease that encodes a potential heavy metal binding protein. Nat Genet 1993;3:14-19.

26 Mercer JF, Livingston J, Hall B, Paynter JA, Begy C, Chandrasekharappa S, Lockhart $P$, Grimes $A$, Bhave M, Siemieniak D, et al. Isolation of a partial candidate gene for Menkes disease by positional cloning. Nat Genet 1993;3:20-5

27 Vulpe C, Levinson B, Whitney S, Packman S, Gitschier J. Isolation of a candidate gene for Menkes disease and evidence that it encodes a coppertransporting ATPase. Nat Genet 1993;3:7-13.

28 Arnesano F, Banci L, Bertini I, Ciofi-Baffoni S, Molteni E, Huffman DL, $\mathrm{O}^{\prime}$ Halloran TV. Metallochaperones and metal-transporting ATPases: a comparative analysis of sequences and structures. Genome Res 2002; 12:255-71.

29 Tumer Z, Moller LB, Horn N. Mutation spectrum of ATP7A, the gene defective in Menkes disease. Adv Exp Med Biol 1999:448:83-95.

30 Hsi G, Cox DW. A comparison of the mutation spectra of Menkes disease and Wilson disease. Hum Genet 2004;114:165-72.

31 Mercer JF, Ambrosini L, Horton S, Gazeas S, Grimes A. Animal models of Menkes disease. Adv Exp Med Biol 1999:448:97-108.

32 Mercer JF, Grimes A, Ambrosini L, Lockhart P, Paynter JA, Dierick H, Glover TW. Mutations in the murine homologue of the Menkes gene in dappled and blotchy mice. Nat Genet 1994:6:374-8.

33 Levinson B, Vulpe C, Elder B, Martin C, Verley F, Packman S, Gitschier J. The mottled gene is the mouse homologue of the Menkes disease gene. Nat Genet 1994:6:369-73.

34 Cecchi C, Biasotto M, Tosi M, Avner P. The mottled mouse as a model for human Menkes disease: identification of mutations in the Atp7a gene. Hum Mol Genet 1997;6:425-33.

35 Grimes A, Hearn CJ, Lockhart P, Newgreen DF, Mercer JF. Molecular basis of the brindled mouse mutant $(\mathrm{Mo}(\mathrm{br}))$ : a murine model of Menkes disease. Hum Mol Genet 1997;6:1037-42.

36 Murata Y, Kodama H, Abe T, Ishida N, Nishimura M, Levinson B, Gitschier J, Packman S. Mutation analysis and expression of the mottled gene in the macular mouse model of Menkes disease. Pediatr Res 1997;42:436-42.

37 Levinson B, Packman S, Gitschier J. Deletion of the promoter region in the Atp7a gene of the mottled dappled mouse. Nat Genet 1997;16:224-5.

38 Mori M, Nishimura M. A serine-to-proline mutation in the copper-transporting P-type ATPase gene of the macular mouse. Mamm Genome 1997;8:407-10.

39 Reed V, Boyd Y. Mutation analysis provides additional proof that mottled is the mouse homologue of Menkes' disease. Hum Mol Genet 1997;6:417-23.

40 Das S, Levinson B, Vulpe C, Whitney S, Gitschier J, Packman S. Similar splicing mutations of the Menkes/mottled copper-transporting ATPase gene in occipital horn syndrome and the blotchy mouse. Am J Hum Genet 1995:56:570-6.

41 George AM, Reed V, Glenister P, Chelly J, Tumer Z, Horn N, Monaco AP, Boyd Y. Analysis of Mnk, the murine homologue of the locus for Menkes disease, in normal and mottled (Mo) mice. Genomics 1994:22:27-35.

42 Mototani Y, Miyoshi I, Okamura T, Moriya T, Meng Y, Yuan Pei X, Kameo S, Kasai N. Phenotypic and genetic characterization of the Atp7a(Mo-Tohm) mottled mouse: a new murine model of Menkes disease. Genomics 2006:87:191-9

43 Llanos RM, Ke BX, Wright M, Deal Y, Monty F, Kramer DR, Mercer JF. Correction of a mouse model of Menkes disease by the human Menkes gene. Biochim Biophys Acta 2006;1762:485-93.

44 Mendelsohn BA, Yin C, Johnson SL, Wilm TP, Solnica-Krezel L, Gitlin JD. Atp7a determines a hierarchy of copper metabolism essential for notochord development. Cell Metab 2006:4:155-62.

45 Ala A, Walker AP, Ashkan K, Dooley JS, Schilsky ML. Wilson's disease. Lancet 2007;369:397-408.

46 Gitlin JD. Wilson disease. Gastroenterology 2003; 125:1868-77.

47 Scheinberg IH, Gitlin D. Deficiency of ceruloplasmin in patients with hepatolenticular degeneration (Wilson's disease). Science 1952;1 16:484-5.

48 Riordan SM, Williams R. The Wilson's disease gene and phenotypic diversity J Hepatol 2001;34:165-71.

49 Harris ZL, Klomp LW, Gitlin JD. Aceruloplasminemia: an inherited neurodegenerative disease with impairment of iron homeostasis. Am J Clin Nutr 1998;67(Suppl):972-7S.

50 Walshe JM. Wilson's disease; new oral therapy. Lancet 1956;270:25-6.

51 Brewer GJ, Dick RD, Yuzbasiyan-Gurkin V, Tankanow R, Young AB, Kluin KJ. Initial therapy of patients with Wilson's disease with tetrathiomolybdate. Arch Neurol 1991:48:42-7.

52 Brewer GJ, Dick RD, Johnson V, Wang Y, Yuzbasiyan-Gurkan V, Kluin K, Fink JK, Aisen A. Treatment of Wilson's disease with ammonium tetrathiomolybdate. I. Initial therapy in 17 neurologically affected patients. Arch Neurol 1994:51:545-54.

53 Bull PC, Thomas GR, Rommens JM, Forbes JR, Cox DW. The Wilson disease gene is a putative copper transporting P-type ATPase similar to the Menkes gene. Nat Genet 1993;5:327-37. 
54 Tanzi RE, Petrukhin K, Chernov I, Pellequer JL, Wasco W, Ross B, Romano DM, Parano E, Pavone L, Brzustowicz LM. The Wilson disease gene is a copper transporting ATPase with homology to the Menkes disease gene. Nat Genet 1993;5:344-50.

55 Yamaguchi $Y$, Heiny ME, Gitlin JD. Isolation and characterization of a human liver CDNA as a candidate gene for Wilson disease. Biochem Biophys Res Commun 1993; 197:271-7.

56 Petrukhin K, Fischer SG, Pirastu M, Tanzi RE, Chernov I, Devoto M, Brzustowicz LM, Cayanis E, Vitale E, Russo JJ. Mapping, cloning and genetic characterization of the region containing the Wilson disease gene. Nat Genet 1993;5:338-43.

57 Michalczyk AA, Rieger J, Allen KJ, Mercer JF, Ackland ML. Defective localization of the Wilson disease protein (ATP7B) in the mammary gland of the toxic milk mouse and the effects of copper supplementation. Biochem J 2000;352:565-71

58 Kuo YM, Gitschier J, Packman S. Developmental expression of the mouse mottled and toxic milk genes suggests distinct functions for the Menkes and Wilson disease copper transporters. Hum Mol Genet 1997;6:1043-9.

59 Kenny S, Cox DW. Wilson disease mutation database. http:// www.medicalgenetics.med.ualberta.ca/wilson/index.php.

60 Ferenci P. Regional distribution of mutations of the ATP7B gene in patients with Wilson disease: impact on genetic testing. Hum Genet 2006;120:151-9.

61 Muller $T$, van de Sluis $B$, Zhernakova A, van Binsbergen $E$, Janecke AR, Bavdekar A, Pandit A, Weirich-Schwaiger H, Witt H, Ellemunter H, Deutsch J, Denk H, Muller W, Sternlieb I, Tanner MS, Wijmenga C. The canine copper toxicosis gene MURR1 does not cause non-Wilsonian hepatic copper toxicosis. J Hepatol 2003:38:164-8.

62 Wijmenga C, Muller T, Murli IS, Brunt T, Feichtinger H, Schonitzer D, Houwen RH, Muller W, Sandkuijl LA, Pearson PL. Endemic Tyrolean infantile cirrhosis is not an allelic variant of Wilson's disease. Eur J Hum Genet 1998;6:624-8.

63 Muller T, Schafer H, Rodeck B, Haupt G, Koch H, Bosse H, Welling P, Lange H, Krech R, Feist D, Muhlendahl KE, Bramswig J, Feichtinger H, Muller W. Familial clustering of infantile cirrhosis in Northern Germany: A clue to the etiology of idiopathic copper toxicosis. J Pediatr 1999;135:189-96.

64 Fuentealba IC, Aburto EM. Animal models of copper-associated liver disease. Comp Hepatol 2003:2:5.

65 Yamaguchi Y, Heiny ME, Shimizu N, Aoki T, Gitlin JD. Expression of the Wilson disease gene is deficient in the Long-Evans Cinnamon rat. Biochem J 1994:301:1-4.

66 Wu J, Forbes JR, Chen HS, Cox DW. The LEC rat has a deletion in the copper transporting ATPase gene homologous to the Wilson disease gene. Nat Genet 1994:541-5.

67 Muramatsu Y, Yamada T, Moralejo DH, Cai Y, Xin X, Miwa Y, Izumi K, Matsumoto K. The rat homologue of the Wilson's disease gene was partially deleted at the $3^{\prime}$ end of its protein-coding region in Long-Evans Cinnamon mutant rats. Res Commun Mol Pathol Pharmacol 1995:89:421-4.

68 Ono T, Fukumoto R, Takada S, Nagao T, Yoshida MC. Responsible gene for hepatitis of the LEC rat (hts) is the homolog of the human Wilson's disease (WD) gene. Transplant Proc 1995;27:1545.

69 Ono T, Fukumoto R, Kondoh Y, Yoshida MC. Deletion of the Wilson's disease gene in hereditary hepatitis LEC rats. Jpn J Genet 1995;70:25-33.

70 Theophilos MB, Cox DW, Mercer JF. The toxic milk mouse is a murine model of Wilson disease. Hum Mol Genet 1996:5:1619-24.

71 Buiakova OI, Xu J, Lutsenko S, Zeitlin S, Das K, Das S, Ross BM, Mekios C, Scheinberg IH, Gilliam TC. Null mutation of the murine ATP7B (Wilson disease) gene results in intracellular copper accumulation and late-onset hepatic nodular transformation. Hum Mol Genet 1999:8:1665-71.

72 Hardy RM, Stevens JB, Stowe CM. Chronic progressive hepatitis in Bedlington terriers associated with elevated liver copper concentrations. Minnesota Veterinarian 1975;15:13-24.

73 Dagenais SL, Guevara-Fujita M, Loechel R, Burgess AC, Miller DE, YuzbasiyanGurkan V, Brewer GJ, Glover TW. The canine copper toxicosis locus is not syntenic with ATP7B or ATX1 and maps to a region showing homology to human 2p21. Mamm Genome 1999:10:753-6.

74 Van de Sluis B, Breen $M$, Nanji $M$, van Wolferen $M$, de Jong $P$, Binns $M M$, Pearson PL, Kuipers J, Rothuizen J, Cox DW, Wijmenga C, van Oost BA. Genetic mapping of the copper toxicosis locus in Bedlington terriers to dog chromosome 10, in a region syntenic to human chromosome region 2p13-pl6. Hum Mol Genet 1999;8:501-7.

75 Klomp AE, van de Sluis B, Klomp LW, Wijmenga C. The ubiquitously expressed MURR 1 protein is absent in canine copper toxicosis. J Hepatol 2003;39:703-9.

76 Van de Sluis B, Rothuizen J, Pearson PL, van Oost BA, Wijmenga C. Identification of a new copper metabolism gene by positional cloning in a purebred dog population. Hum Mol Genet 2002;11:165-73.

77 Forman OP, Boursnell ME, Dunmore BJ, Stendall N, van den Sluis B, Fretwell N, Jones C, Wiimenga C, Rothuizen J, van Oost BA, Holmes NG, Binns MM, Jones P. Characterization of the COMMD1 (MURR1) mutation causing copper toxicosis in Bedlington terriers. Anim Genet 2005;36:497-501.

78 Wu ZY, Zhao GX, Chen WJ, Wang N, Wan B, Lin MT, Murong SX, Yu L. Mutation analysis of 218 Chinese patients with Wilson disease revealed no correlation between the canine copper toxicosis gene MURR1 and Wilson disease. J Mol Med 2006:1-5.

79 Coronado VA, Bonneville JA, Nazer H, Roberts EA, Cox DW. COMMD1 (MURR 1) as a candidate in patients with copper storage disease of undefined etiology. Clin Genet 2005;68:548-51.

80 Stuehler B, Reichert J, Stremmel W, Schaefer M. Analysis of the human homologue of the canine copper toxicosis gene MURR1 in Wilson disease patients. J Mol Med 2004;82:629-34.
81 Weiss KH, Merle U, Schaefer M, Ferenci P, Fullekrug J, Stremmel W. Copper toxicosis gene MURRI is not changed in Wilson disease patients with normal blood ceruloplasmin levels. World J Gastroenterol 2006;12:2239-42.

82 Lovicu M, Dessi V, Lepori MB, Zappu A, Zancan L, Giacchino R, Marazzi MG, lorio R, Vegnente A, Vajro P, Maggiore G, Marcellini M, Barbera C, Kostic V Farci AM, Solinas A, Altuntas B, Yuce A, Kocak N, Tsezou A, De Virgiliis S, Cao A, Loudianos $G$. The canine copper toxicosis gene MURR1 is not implicated in the pathogenesis of Wilson disease. J Gastroenterol 2006;41:582-7.

83 Hyun C, Lavulo LT, Filippich U. Evaluation of haplotypes associated with copper toxicosis in Bedlington terriers in Australia. Am J Vet Res 2004;65:1573-9.

84 Coronado VA, Damaraju D, Kohijoki R, Cox DW. New haplotypes in the Bedlington terrier indicate complexity in copper toxicosis. Mamm Genome 2003; 14:483-91.

85 Burstein E, Hoberg JE, Wilkinson AS, Rumble JM, Csomos RA, Komarck CM, Maine GN, Wilkinson JC, Mayo MW, Duckett CS. COMMD proteins, a novel family of structural and functional homologs of MURR1. J Biol Chem 2005;280:22222-32.

86 Royce PM, Camakaris J, Danks DM. Reduced lysyl oxidase activity in skin fibroblasts from patients with Menkes' syndrome. Biochem J 1980;192:579-86.

87 Petris MJ, Strausak D, Mercer JF. The Menkes copper transporter is required for the activation of tyrosinase. Hum Mol Genet 2000;9:2845-51.

88 Kodama H, Okabe I, Yanagisawa M, Kodama Y. Copper deficiency in the mitochondria of cultured skin fibroblasts from patients with Menkes syndrome. $\mathrm{J}$ Inherit Metab Dis 1989;12:386-9.

89 El Meskini R, Culotta VC, Mains RE, Eipper BA. Supplying copper to the cuproenzyme peptidylglycine alpha-amidating monooxygenase. J Biol Chem 2003;278: 12278-84.

90 Qin Z, Itoh S, Jeney V, Ushio-Fukai M, Fukai T. Essential role for the Menkes ATPase in activation of extracellular superoxide dismutase: implication for vascular oxidative stress. FASEB J 2006:20:334-6.

91 Chan WY, Garnica AD, Rennert OM. Cell culture studies of Menkes kinky hair disease. Clin Chim Acta 1978;88:495-507.

92 La Fontaine SL, Firth SD, Camakaris J, Englezou A, Theophilos MB, Petris MJ Howie M, Lockhart PJ, Greenough M, Brooks H, Reddel RR, Mercer JF. Correction of the copper transport defect of Menkes patient fibroblasts by expression of the Menkes and Wilson ATPases. J Biol Chem 1998:273:31375-80.

93 Camakaris J, Petris M, Bailey L, Shen P, Lockhart P, Glover TW, Barcroft C, Patton J, Mercer JF. Gene amplification of the Menkes (MNK; ATP7A) P-type ATPase gene of $\mathrm{CHO}$ cells is associated with copper resistance and enhanced copper efflux. Hum Mol Genet 1995:4:2117-23.

94 La Fontaine S, Firth SD, Lockhart PJ, Brooks H, Parton RG, Camakaris J, Mercer JF. Functional analysis and intracellular localization of the human menkes protein (MNK) stably expressed from a cDNA construct in Chinese hamster ovary cells (CHO-K1). Hum Mol Genet 1998;7:1293-300.

95 Katano K, Safaei R, Samimi G, Holzer A, Rochdi M, Howell SB. The copper export pump ATP7B modulates the cellular pharmacology of carboplatin in ovarian carcinoma cells. Mol Pharmacol 2003;64:466-73.

96 Voskoboinik I, Brooks H, Smith S, Shen P, Camakaris J. ATP-dependent copper transport by the Menkes protein in membrane vesicles isolated from cultured Chinese hamster ovary cells. FEBS Lett 1998;435:178-82.

97 Voskoboinik I, Greenough M, La Fontaine S, Mercer JF, Camakaris J. Functional studies on the Wilson copper P-type ATPase and toxic milk mouse mutant. Biochem Biophys Res Commun 2001;281:966-70.

98 Hung YH, Layton MJ, Voskoboinik I, Mercer JF, Camakaris J. Purification and membrane reconstitution of catalytically active Menkes copper-transporting Ptype ATPase (MNK; ATP7A). Biochem J 2007;401:569-79.

99 van Dongen EM, Dekkers LM, Spijker K, Meijer EW, Klomp LW, Merkx M. Ratiometric fluorescent sensor proteins with subnanomolar affinity for $\mathrm{Zn}(\mathrm{II})$ based on copper chaperone domains. J Am Chem Soc 2006;128:10754-62.

100 Zeng L, Miller EW, Pralle A, Isacoff EY, Chang CJ. A selective turn-on fluorescent sensor for imaging copper in living cells. J Am Chem Soc 2006; 128:10-11.

101 Yang L, McRae R, Henary MM, Patel R, Lai B, Vogt S, Fahrni CJ. Imaging of the intracellular topography of copper with a fluorescent sensor and by synchrotron $x$-ray fluorescence microscopy. Proc Natl Acad Sci U S A 2005; 102: $11179-84$.

102 van den Berghe PV, Folmer DE, Malingre $H E$, van Beurden $E$, Klomp $A E$, van de Sluis B, Merkx M, Berger R, Klomp LW. Human copper transporter 2 is localized in late endosomes and lysosomes and facilitates cellular copper uptake. Biochem J 2007;407:49-59.

103 Yuan DS, Stearman R, Dancis A, Dunn T, Beeler T, Klausner RD. The Menkes/ Wilson disease gene homologue in yeast provides copper to a ceruloplasminlike oxidase required for iron uptake. Proc Natl Acad Sci U S A 1995:9:2632-6.

104 Yuan DS, Dancis A, Klausner RD. Restriction of copper export in Saccharomyces cerevisiae to a late Golgi or post-Golgi compartment in the secretory pathway. J Biol Chem 1997;272:25787-93.

105 Hung IH, Suzuki M, Yamaguchi Y, Yuan DS, Klausner RD, Gitlin JD. Biochemical characterization of the Wilson disease protein and functional expression in the yeast Saccharomyces cerevisiae. J Biol Chem 1997:272:21461-6.

106 Payne AS, Gitlin JD. Functional expression of the menkes disease protein reveals common biochemical mechanisms among the copper-transporting Ptype ATPases. J Biol Chem 1998:273:3765-70.

107 Kuhlbrandt W. Biology, structure and mechanism of P-type ATPases. Nat Rev Mol Cell Biol 2004;5:282-95.

108 Lutsenko S, Petrukhin K, Cooper MJ, Gilliam CT, Kaplan JH. N-terminal domains of human copper-transporting adenosine triphosphatases (the 
Wilson's and Menkes disease proteins) bind copper selectively in vivo and in vitro with stoichiometry of one copper per metal-binding repeat. J Biol Chem 1997;272:18939-44

109 DiDonato M, Narindrasorasak S, Forbes JR, Cox DW, Sarkar B. Expression, purification, and metal binding properties of the $\mathrm{N}$-terminal domain from the wilson disease putative copper-transporting ATPase (ATP7B). J Biol Chem 1997;272:33279-82.

110 Tsivkovskii R, MacArthur BC, Lutsenko S. The Lys 1010-Lys 1325 fragment of the Wilson's disease protein binds nucleotides and interacts with the $\mathrm{N}$-terminal domain of this protein in a copper-dependent manner. J Biol Chem 2001;276:2234-42.

111 Voskoboinik I, Mar J, Strausak D, Camakaris J. The regulation of catalytic activity of the Menkes copper-translocating P-type ATPase. Role of high affinity copper-binding sites. J Biol Chem $2001 ; 276: 28620-7$.

112 Huster D, Lutsenko S. The distinct roles of the $\mathrm{N}$-terminal copper-binding sites in regulation of catalytic activity of the Wilson's disease protein. J Biol Chem 2003;278:32212-18.

113 Tsivkovskii R, Eisses JF, Kaplan JH, Lutsenko S. Functional properties of the copper-transporting ATPase ATP7B (the Wilson's disease protein) expressed in insect cells. J Biol Chem 2002;277:976-83.

114 Petris MJ, Voskoboinik I, Cater M, Smith K, Kim BE, Llanos RM, Strausak D, Camakaris J, Mercer JF. Copper-regulated trafficking of the Menkes disease copper ATPase is associated with formation of a phosphorylated catalytic intermediate. J Biol Chem 2002;277:46736-42.

115 Dijkstra M, In 't Veld G, van den Berg GJ, Muller M, Kuipers F, Vonk RJ. Adenosine triphosphate-dependent copper transport in isolated rat liver plasma membranes. J Clin Invest 1995:95:412-16.

116 Bingham MJ, Burchell A, McArdle HJ. Identification of an ATP-dependent copper transport system in endoplasmic reticulum vesicles isolated from rat liver. J Physiol 1995:482:583-7.

117 Morgan CT, Tsivkovskii R, Kosinsky YA, Efremov RG, Lutsenko S. The distinct functional properties of the nucleotide-binding domain of ATP7B, the human copper-transporting ATPase: analysis of the Wilson disease mutations E1064A, H1069Q, R1151H, and C1104F. J Biol Chem 2004;279:36363-71.

118 Dmitriev O, Tsivkovskii R, Abildgaard F, Morgan CT, Markley JL, Lutsenko S. Solution structure of the $\mathrm{N}$-domain of Wilson disease protein: distinct nucleotide-binding environment and effects of disease mutations. Proc Nat Acad Sci U S A 2006; 103:5302-7.

119 Efremov RG, Kosinsky YA, Nolde DE, Tsivkovskii R, Arseniev AS, Lutsenko S Molecular modelling of the nucleotide-binding domain of Wilson's disease protein: location of the ATP-binding site, domain dynamics and potential effects of the major disease mutations. Biochem J 2004;382:293-305.

120 Voskoboinik I, Strausak D, Greenough M, Brooks H, Petris M, Smith S, Mercer JF, Camakaris J. Functional analysis of the N-terminal CXXC metal binding motifs in the human menkes copper-transporting P-type ATPase expressed in cultured mammalian cells. J Biol Chem 1999;274:22008-12.

121 Yamaguchi Y, Heiny ME, Suzuki M, Gitlin JD. Biochemical characterization and intracellular localization of the Menkes disease protein. Proc Natl Acad Sci U S A 1996;93:14030-5.

122 Petris MJ, Mercer JF, Culvenor JG, Lockhart P, Gleeson PA, Camakaris J. Ligand-regulated transport of the Menkes copper P-type ATPase efflux pump from the Golgi apparatus to the plasma membrane: a novel mechanism of regulated trafficking. Embo $J$ 1996;156084-95

123 Harada M, Sakisaka S, Terada K, Kimura R, Kawaguchi T, Koga H, Taniguchi E, Sasatomi K, Miura N, Suganuma T, Fujita H, Furuta K, Tanikawa K, Sugiyama T, Sata M. Role of ATP7B in biliary copper excretion in a human hepatoma cell line and normal rat hepatocytes. Gastroenterology 2000;118:921-8.

124 Harada M, Kawaguchi T, Kumemura H, Terada K, Ninomiya H, Taniguchi E, Hanada S, Baba S, Maeyama M, Koga H, Ueno T, Furuta K, Suganuma T, Sugiyama T, Sata $M$. The Wilson disease protein ATP7B resides in the late endosomes with Rab7 and the Niemann-Pick $\mathrm{Cl}$ protein. Am J Pathol 2005; 166:499-510.

125 Lutsenko S, Cooper MJ. Localization of the Wilson's disease protein product to mitochondria. Proc Natl Acad Sci U S A 1998:95:6004-9.

126 Huster D, Hoppert M, Lutsenko S, Zinke J, Lehmann C, Mossner J, Berr F, Caca K. Defective cellular localization of mutant ATP7B in Wilson's disease patients and hepatoma cell lines. Gastroenterology 2003;124:335-45.

127 Forbes JR, Cox DW. Copper-dependent trafficking of Wilson disease mutant ATP7B proteins. Hum Mol Genet 2000;9:1927-35.

128 Roelofsen H, Wolters H, Van Luyn MJ, Miura N, Kuipers F, Vonk RJ. Copperinduced apical trafficking of ATP7B in polarized hepatoma cells provides a mechanism for biliary copper excretion. Gastroenterology 2000;1 19:782-93.

129 Schaefer M, Roelofsen H, Wolters H, Hofmann WJ, Muller M, Kuipers F, Stremmel W, Vonk RJ. Localization of the Wilson's disease protein in human liver. Gastroenterology 1999;117:1380-5.

130 Schaefer M, Hopkins RG, Failla ML, Gitlin JD. Hepatocyte-specific localization and copper-dependent trafficking of the Wilson's disease protein in the liver. Am J Physiol 1999;276:G639-46.

131 Mercer JF, Barnes N, Stevenson J, Strausak D, Llanos RM. Copper-induced trafficking of the CU-ATPases: a key mechanism for copper homeostasis. Biometals 2003;16:175-84.

132 La Fontaine S, Theophilos MB, Firth SD, Gould R, Parton RG, Mercer JF. Effect of the toxic milk mutation (tx) on the function and intracellular localization of Wnd, the murine homologue of the Wilson copper ATPase. Hum Mol Genet 2001;10:361-70.

133 Guo Y, Nyasae L, Braiterman LT, Hubbard AL. NH2-terminal signals in ATP7B Cu-ATPase mediate its $\mathrm{Cu}$-dependent anterograde traffic in polarized hepatic cells. Am J Physiol Gastrointest Liver Physiol 2005;289:G904-16.
134 Petris MJ, Mercer JF. The Menkes protein (ATP7A; MNK) cycles via the plasma membrane both in basal and elevated extracellular copper using a $\mathrm{C}$-terminal di-leucine endocytic signal. Hum Mol Genet 1999;8:2107-15.

135 Nyasae L, Bustos R, Braiterman L, Eipper B, Hubbard A. Dynamics of endogenous ATP7A (Menkes protein) in intestinal epithelial cells: copperdependent redistribution between two intracellular sites. Am J Physiol Gastrointest Liver Physiol 2007;292:G1 181-94.

136 Greenough M, Pase L, Voskoboinik I, Petris MJ, O'Brien AW, Camakaris J. Signals regulating trafficking of Menkes (MNK; ATP7A) copper-translocating $P$ type ATPase in polarized MDCK cells. Am J Physiol Cell Physiol 2004;287: C1463-71.

137 Monty JF, Llanos RM, Mercer JF, Kramer DR. Copper exposure induces trafficking of the menkes protein in intestinal epithelium of ATP7A transgenic mice. J Nutr 2005; 135:2762-6.

138 Ravia JJ, Stephen RM, Ghishan FK, Collins JF. Menkes Copper ATPase (Atp7a) is a novel metal-responsive gene in rat duodenum, and immunoreactive protein is present on brush-border and basolateral membrane domains. J Biol Chem 2005;280:36221-7.

139 Ke BX, Llanos RM, Wright M, Deal Y, Mercer JF. Alteration of copper physiology in mice overexpressing the human Menkes protein ATP7A. Am J Physiol Regul Integr Comp Physiol 2006;290:R1 460-7.

140 Cater MA, La Fontaine S, Shield K, Deal Y, Mercer JF. ATP7B mediates vesicular sequestration of copper: insight into biliary copper excretion. Gastroenterology 2006; 130:493-506.

141 Ambrosini L, Mercer JF. Defective copper-induced trafficking and localization of the Menkes protein in patients with mild and copper-treated classical Menkes disease. Hum Mol Genet 1999;8:1547-55.

142 Kim BE, Smith K, Petris MJ. A copper treatable Menkes disease mutation associated with defective trafficking of a functional Menkes copper ATPase. J Med Genet 2003;40:290-5.

143 Forbes JR, Cox DW. Functional characterization of missense mutations in ATP7B: Wilson disease mutation or normal variant? Am J Hum Genet 1998;63:1663-74.

144 Harada M, Sakisaka S, Terada K, Kimura R, Kawaguchi T, Koga H, Kim M, Taniguchi E, Hanada S, Suganuma T, Furuta K, Sugiyama T, Sata M. A mutation of the Wilson disease protein, ATP7B, is degraded in the proteasomes and forms protein aggregates. Gastroenterology 2001;120:967-74.

145 Qi M, Byers PH. Constitutive skipping of alternatively spliced exon 10 in the ATP7A gene abolishes Golgi localization of the menkes protein and produces the occipital horn syndrome. Hum Mol Genet 1998;7:465-9.

$146 \mathrm{Kim}$ BE, Smith K, Meagher CK, Petris MJ. A conditional mutation affecting localization of the Menkes disease copper ATPase. Suppression by copper supplementation. J Biol Chem 2002;277:44079-84.

147 Francis MJ, Jones EE, Levy ER, Ponnambalam S, Chelly J, Monaco AP. A Golgi localization signal identified in the Menkes recombinant protein. Hum Mol Genet 1998;7:1245-52.

148 Payne AS, Kelly EJ, Gitlin JD. Functional expression of the Wilson disease protein reveals mislocalization and impaired copper-dependent trafficking of the common H1069Q mutation. Proc Natl Acad Sci U S A 1998;95: 10854-9.

149 de Bie P, van de Sluis B, Burstein E, Berghe PVE, Muller P, Berger R, Gitlin JD, Wijmenga $C$, Klomp LWJ. Distinct Wilson-disease mutations in ATP7B are associated with enhanced binding to COMMD1 and reduced stability of ATP7B. Gastroenterology 2007;398:63-71

150 Meusser B, Hirsch C, Jarosch E, Sommer T. ERAD: the long road to destruction. Nat Cell Biol 2005:7:766-72.

151 Cheng SH, Gregory RJ, Marshall J, Paul S, Souza DW, White GA, O'Riordan CR, Smith AE. Defective intracellular transport and processing of CFTR is the molecular basis of most cystic fibrosis. Cell 1990;63:827-34.

152 Vanderwerf SM, Cooper MJ, Stetsenko IV, Lutsenko S. Copper specifically regulates intracellular phosphorylation of the Wilson's disease protein, a human copper-transporting ATPase. J Biol Chem $2001 ; 276: 36289-94$.

153 Voskoboinik I, Fernando R, Veldhuis N, Hannan KM, Marmy-Conus N, Pearson RB, Camakaris J. Protein kinase-dependent phosphorylation of the Menkes copper P-type ATPase. Biochem Biophys Res Commun 2003;303:337-42

154 Lutsenko S, Petris MJ. Function and regulation of the mammalian coppertransporting ATPases: insights from biochemical and cell biological approaches. J Membr Biol 2003;191:1-12.

155 Vanderwerf SM, Lutsenko S. The Wilson's disease protein expressed in Sf9 cells is phosphorylated. Biochem Soc Trans 2002;30:739-41

156 Stelzl U, Worm U, Lalowski M, Haenig C, Brembeck FH, Goehler H, Stroedicke M, Zenkner M, Schoenherr A, Koeppen S, Timm J, Mintzlaff S, Abraham C, Bock N, Kietzmann S, Goedde A, Toksoz E, Droege A, Krobitsch S, Korn B, Birchmeier W, Lehrach H, Wanker EE. A human protein-protein interaction network: a resource for annotating the proteome. Cell $2005 ; 122: 957-68$

157 Rae TD, Schmidt PJ, Pufahl RA, Culotta VC, O'Halloran TV. Undetectable intracellular free copper: the requirement of a copper chaperone for superoxide dismutase. Science 1999;284:805-8.

158 Klomp LW, Lin SJ, Yuan DS, Klausner RD, Culotta VC, Gitlin JD. Identification and functional expression of $\mathrm{HAH1}$, a novel human gene involved in copper homeostasis. J Biol Chem 1997;272:9221-6.

159 Lin SJ, Pufahl RA, Dancis A, O'Halloran TV, Culotta VC. A role for the Saccharomyces cerevisiae ÁTX1 gene in copper trafficking and iron transport. J Biol Chem 1997;272:9215-20.

160 Hamza I, Faisst A, Prohaska J, Chen J, Gruss P, Gitlin JD. The metallochaperone Atox 1 plays a critical role in perinatal copper homeostasis. Proc Natl Acad Sci U S A 2001;98:6848-52. 
161 Hamza I, Schaefer M, Klomp LW, Gitlin JD. Interaction of the copper chaperone HAHI with the Wilson disease protein is essential for copper homeostasis. Proc Natl Acad Sci U S A 1999:96:13363-8.

162 Larin D, Mekios C, Das K, Ross B, Yang AS, Gilliam TC. Characterization of the interaction between the Wilson and Menkes disease proteins and the cytoplasmic copper chaperone, HAHlp. J Biol Chem 1999;274:28497-504.

163 Pufahl RA, Singer CP, Peariso KL, Lin SJ, Schmidt PJ, Fahrni CJ, Culotta VC, Penner-Hahn JE, O'Halloran TV. Metal ion chaperone function of the soluble Cu(I) receptor Atx1. Science 1997;278:853-6.

164 Multhaup G, Strausak D, Bissig KD, Solioz M. Interaction of the CopZ copper chaperone with the CopA copper ATPase of Enterococcus hirae assessed by surface plasmon resonance. Biochem Biophys Res Commun 2001;288:172-7.

165 Banci L, Bertini I, Ciofi-Baffoni S, Del Conte R, Gonnelli L. Understanding copper trafficking in bacteria: interaction between the copper transport protein CopZ and the N-terminal domain of the copper ATPase CopA from Bacillus subtilis. Biochemistry 2003:42:1939-49.

166 Radford DS, Kihlken MA, Borrelly GP, Harwood CR, Le Brun NE, Cavet JS. CopZ from Bacillus subtilis interacts in vivo with a copper exporting CPx-type ATPase CopA. FEMS Microbiol Lett 2003;220:105-12.

167 Hung IH, Casareno RL, Labesse G, Mathews FS, Gitlin JD. HAH1 is a copperbinding protein with distinct amino acid residues mediating copper homeostasis and antioxidant defense. J Biol Chem 1998;273:1749-54.

168 Strausak D, Howie MK, Firth SD, Schlicksupp A, Pipkorn R, Multhaup G, Mercer JF. Kinetic analysis of the interaction of the copper chaperone Atox 1 with the metal binding sites of the Menkes protein. J Biol Chem 2003;278:20821-7.

169 Pornoy ME, Rosenzweig AC, Rae T, Huffman DL, O'Halloran TV, Culotta VC. Structure-function analyses of the ATX1 metallochaperone. J Biol Chem 1999;274:15041-5.

170 Arnesano F, Banci L, Bertini I, Cantini F, Ciofi-Baffoni S, Huffman DL, $\mathrm{O}^{\prime}$ Halloran TV. Characterization of the binding interface between the copper chaperone Atx1 and the first cytosolic domain of Ccc2 ATPase. J Biol Chem $2001 ; 276: 41365-76$.

171 Van Dongen EM, Klomp LW, Merkx M. Copper-dependent protein-protein interactions studied by yeast two-hybrid analysis. Biochem Biophys Res Commun 2004;323:789-95.

172 Yatsunyk LA, Rosenzweig AC. Cu(I) binding and transfer by the $\mathrm{N}$ terminus of the Wilson disease protein. J Biol Chem 2007;282:8622-31.

173 Walker JM, Tsivkovskii R, Lutsenko S. Metallochaperone Atox 1 transfers copper to the NH2-terminal domain of the Wilson's disease protein and regulates its catalytic activity. J Biol Chem 2002;277:27953-9.

174 Ralle M, Lutsenko S, Blackburn NJ. Copper transfer to the $\mathrm{N}$-terminal domain of the Wilson disease protein (ATP7B): X-ray absorption spectroscopy of reconstituted and chaperone-loaded metal binding domains and their interaction with exogenous ligands. J Inorg Biochem 2004;98:765-74.

175 Walker JM, Huster D, Ralle M, Morgan CT, Blackburn NJ, Lutsenko S. The Nterminal metal-binding site 2 of the Wilson's Disease Protein plays a key role in the transfer of copper from Atox1. J Biol Chem 2004;279:15376-84.

176 Hamza I, Prohaska J, Gitlin JD. Essential role for Atox 1 in the copper-mediated intracellular trafficking of the Menkes ATPase. Proc Natl Acad Sci U S A 2003; 100:1215-20

177 Tao TY, Liu F, Klomp L, Wijmenga C, Gitlin JD. The copper toxicosis gene product Murr1 directly interacts with the Wilson disease protein. J Biol Chem 2003;278:41593-6

178 Burstein E, Ganesh L, Dick RD, van De Sluis B, Wilkinson JC, Klomp LW Wijmenga C, Brewer GJ, Nabel GJ, Duckett CS. A novel role for XIAP in copper homeostasis through regulation of MURR1. Embo J 2004;23:244-54.

179 Ganesh L, Burstein E, Guha-Niyogi A, Louder MK, Mascola JR, Klomp LW, Wijmenga C, Duckett CS, Nabel GJ. The gene product Murr 1 restricts HIV-1 replication in resting CD4+ lymphocytes. Nature 2003;426:853-7.

180 De Bie P, van de Sluis B, Klomp L, Wijmenga C. The Many Faces of the Copper Metabolism Protein MURR1/COMMD1. J Hered 2005;96:803-11.

181 Maine GN, Mao X, Komarck CM, Burstein E. COMMD1 promotes the ubiquitination of NF-kappaB subunits through a cullin-containing ubiquitin ligase. Embo J 2007;26:436-47.

182 van de Sluis B, Muller P, Duran K, Chen A, Groot AJ, Klomp LW, Liu PP Wijmenga $C$. Increased activity of hypoxia-inducible factor 1 is associated with early embryonic lethality in Commd1 null mice. Mol Cell Biol 2007; 27:4142-56.

183 Biasio W, Chang T, McIntosh CJ, McDonald FJ. Identification of Murr1 as a regulator of the human delta epithelial sodium channel. J Biol Chem 2004;279:5429-34.

184 De Bie P, van de Sluis B, Burstein E, Duran KJ, Berger R, Duckett CS, Wijmenga C, Klomp LW. Characterization of COMMD protein-protein interactions in NF-kappaB signalling. Biochem J 2006;398:63-71.

185 Greene WC. How resting T cells deMURR HIV infection. Nat Immunol 2004;5:18-19.

186 Bertinato J, L'Abbe MR. Copper modulates the degradation of copper chaperone for $\mathrm{Cu}, \mathrm{Zn}$ superoxide dismutase by the $26 \mathrm{~S}$ proteosome. J Biol Chem 2003;278:35071-8.

187 Nittis T, Gitlin JD. Role of copper in the proteosome-mediated degradation of the multicopper oxidase hephaestin. J Biol Chem 2004;279:25696-702.

188 Nadeau JH. Modifier genes in mice and humans. Nat Rev Genet 2001;2:165-74

189 Cutting GR. Modifier genetics: cystic fibrosis. Annu Rev Genomics Hum Genet 2005;6:237-60

190 Boyle MP. Strategies for identifying modifier genes in cystic fibrosis. Proc Am Thorac Soc 2007;4:52-7.
191 Grubenbecher S, Stuve O, Hefter H, Korth C. Prion protein gene codon 129 modulates clinical course of neurological Wilson disease. Neuroreport 2006;17:549-52.

192 Merle U, Stremmel W, Gessner R. Influence of homozygosity for methionine at codon 129 of the human prion gene on the onset of neurological and hepatic symptoms in Wilson disease. Arch Neurol 2006:63:982-5.

193 Schiefermeier M, Kollegger H, Madl C, Polli C, Oder W, Kuhn H, Berr F, Ferenci $P$. The impact of apolipoprotein $E$ genotypes on age at onset of symptoms and phenotypic expression in Wilson's disease. Brain 2000;123:585-90

194 Gu YH, Kodama H, Du SL. Apolipoprotein E genotype analysis in Chinese Han ethnic children with Wilson's disease, with a concentration on those homozygous for R778L. Brain Dev 2005;27:551-3.

195 Paulsen M, Lund C, Akram Z, Winther JR, Horn N, Moller LB. Evidence that translation reinitiation leads to a partially functional Menkes protein containing two copper-binding sites. Am J Hum Genet 2006;79:214-29.

196 Kim BE, Petris MJ. Phenotypic diversity of menkes disease in mottled mice is associated with defects in localization and trafficking of the ATP7A protein. J Med Genet, 2007; doi:10.1136/img.2007.049627.

197 Gromadzka G, Schmidt HH, Genschel J, Bochow B, Rodo M, Tarnacka B, Litwin T, Chabik G, Czlonkowska A. Frameshift and nonsense mutations in the gene for ATPase7B are associated with severe impairment of copper metabolism and with an early clinical manifestation of Wilson's disease. Clin Genet 2005;68:524-32

198 Thomas GR, Forbes JR, Roberts EA, Walshe JM, Cox DW. The Wilson disease gene: spectrum of mutations and their consequences. Nat Genet 1995;9:210-7.

199 Panagiotakaki E, Tzetis M, Manolaki N, Loudianos G, Papatheodorou A, Manesis E, Nousia-Arvanitakis S, Syriopoulou V, Kanavakis E. Genotypephenotype correlations for a wide spectrum of mutations in the Wilson disease gene (ATP7B). Am J Med Genet A 2004;131:168-73.

200 Kusuda Y, Hamaguchi K, Mori T, Shin R, Seike M, Sakata T. Novel mutations of the ATP7B gene in Japanese patients with Wilson disease. J Hum Genet 2000:45:86-91.

201 Mercer JF. The molecular basis of copper-transport diseases. Trends Mol Med $2001 ; 7: 64-9$

202 Ronce N, Moizard MP, Robb L, Toutain A, Villard L, Moraine C. A C2055T transition in exon 8 of the ATP7A gene is associated with exon skipping in an occipital horn syndrome family. Am J Hum Genet 1997;61:233-8.

203 Moller LB, Tumer Z, Lund C, Petersen C, Cole T, Hanusch R, Seidel J, Jensen LR Horn N. Similar splice-site mutations of the ATP7A gene lead to different phenotypes: classical Menkes disease or occipital horn syndrome. Am J Hum Genet 2000;66:1211-20.

204 Gu YH, Kodama H, Murata Y, Mochizuki D, Yanagawa Y, Ushiïima H, Shiba T, Lee CC. ATP7A gene mutations in 16 patients with Menkes disease and a patient with occipital horn syndrome. Am J Med Genet 2001 ;99:217-22.

205 Donsante A, Tang J, Godwin SC, Holmes CS, Goldstein DS, Bassuk A Kaler SG. Differences in ATP7A gene expression underlie intra-familial variability in Menkes disease/occipital horn syndrome. J Med Genet 2007;44:492-7

206 Stapelbroek JM, Bollen CW, van Amstel JK, van Erpecum KJ, van Hattum J, van den Berg LH, Klomp LW, Houwen RH. The H1069Q mutation in ATP7B is associated with late and neurologic presentation in Wilson disease: results of a meta-analysis. J Hepatol 2004;41:758-63.

207 Butler P, Mclntyre N, Mistry PK. Molecular diagnosis of Wilson disease. Mol Genet Metab 2001;72:223-30

208 Caca K, Ferenci P, Kuhn HJ, Polli C, Willgerodt H, Kunath B, Hermann W, Mossner J, Berr F. High prevalence of the H1069Q mutation in East German patients with Wilson disease: rapid detection of mutations by limited sequencing and phenotype-genotype analysis. J Hepatol 2001;35:575-81.

209 Firneisz G, Lakatos PL, Szalay F, Polli C, Glant TT, Ferenci P. Common mutations of ATP7B in Wilson disease patients from Hungary. Am J Med Genet 2002;108:23-8

210 Houwen RH, Juyn J, Hoogenraad TU, Ploos van Amstel JK, Berger R. H714Q mutation in Wilson disease is associated with late, neurological presentation. J Med Genet 1995;32:480-2.

211 Maier-Dobersberger T, Ferenci P, Polli C, Balac P, Dienes HP, Kaserer K Datz C, Vogel W, Gangl A. Detection of the His1069GIn mutation in Wilson disease by rapid polymerase chain reaction. Ann Intern Med 1997;127:21-6.

212 Waldenstrom E, Lagerkvist A, Dahlman T, Westermark K, Landegren U. Efficient detection of mutations in Wilson disease by manifold sequencing. Genomics 1996:37:303-9.

213 Czlonkowska A, Rodo M, Gajda J, Ploos van Amstel HK, Juyn J, Houwen RH Very high frequency of the His 1069 Gln mutation in Polish Wilson disease patients. J Neurol 1997;244:591-2.

214 Shah AB, Chernov I, Zhang HT, Ross BM, Das K, Lutsenko S, Parano E, Pavone L, Evgrafov O, Ivanova-Smolenskaya IA, Anneren G, Westermark K, Urrutia FH, Penchaszadeh GK, Sternlieb I, Scheinberg IH, Gilliam TC, Petrukhin K. Identification and analysis of mutations in the Wilson disease gene (ATP7B): population frequencies, genotype-phenotype correlation, and functional analyses. Am J Hum Genet 1997;61:317-28.

215 Gromadzka G Schmidt HH, Genschel J, Bochow B, Rodo M, Tarnacka B, Litwin T, Chabik G, Czlonkowska A. p.H1069Q mutation in ATP7B and biochemical parameters of copper metabolism and clinical manifestation of Wilson's disease. Mov Disord 2006;21:245-8.

216 Duc HH, Hefter H, Stremmel W, Castaneda-Guillot C, Hernandez Hernandez A Cox DW, Auburger G. His $1069 \mathrm{Gln}$ and six novel Wilson disease mutations: analysis of relevance for early diagnosis and phenotype. Eur J Hum Genet 1998;6:616-23. 
217 Ivanova-Smolenskaya IA, Ovchinnikov IV, Karabanov AV, Deineko NL, Poleshchuk VV, Markova ED, Illarioshkin SN. The His 1069Gln mutation in the ATP7B gene in Russian patients with Wilson disease. J Med Genet 1999;36:174

218 Tarnacka B, Gromadzka G, Rodo M, Mierzejewski P, Czloonkowska A. Frequency of His $1069 \mathrm{Gln}$ and Gly 1267 Lys mutations in Polish Wilson's disease population. Eur J Neurol 2000;7:495-8.

219 Loudianos G, Kostic V, Solinas P, Lovicu M, Dessi V, Svetel M, Major T, Cao A. Characterization of the molecular defect in the ATP7B gene in Wilson disease patients from Yugoslavia. Genet Test 2003;7:107-12.

220 Vrabelova S, Letocha O, Borsky M, Kozak L. Mutation analysis of the ATP7B gene and genotype/phenotype correlation in 227 patients with Wilson disease. Mol Genet Metab 2005;86:277-85

221 Wu ZY, Wang N, Lin MT, Fang L, Murong SX, Yu L. Mutation analysis and the correlation between genotype and phenotype of Arg778Leu mutation in chinese patients with Wilson disease. Arch Neurol 2001:58:971-6.

222 Yoo HW. Identification of novel mutations and the three most common mutations in the human ATP7B gene of Korean patients with Wilson disease. Genet Med 2002:4(Suppl):43S-8S.

223 Petrukhin K, Lutsenko S, Chernov I, Ross BM, Kaplan JH, Gilliam TC Characterization of the Wilson disease gene encoding a P-type copper transporting ATPase: genomic organization, alternative splicing, and structure/ function predictions. Hum Mol Genet 1994:1647-56

224 Okada T, Shiono Y, Hayashi H, Satoh H, Sawada T, Suzuki A, Takeda Y, Yano M, Michitaka K, Onii M, Mabuchi H. Mutational analysis of ATP7B and genotype-phenotype correlation in Japanese with Wilson's disease. Hum Mutat 2000;15:454-62

225 Liu XQ, Zhang YF, Liu TT, Hsiao KJ, Zhang JM, Gu XF, Bao KR, Yu LH, Wang MX. Correlation of ATP7B genotype with phenotype in Chinese patients with Wilson disease. World J Gastroenterol 2004;10:590-3.

226 Gu YH, Kodama H, Du SL, Gu QJ, Sun HJ, Ushijima H. Mutation spectrum and polymorphisms in ATP7B identified on direct sequencing of all exons in Chinese Han and Hui ethnic patients with Wilson's disease. Clin Genet 2003;64(6):479-84

227 Wijmenga C, Klomp LW. Molecular regulation of copper excretion in the liver. Proc Nutr Soc 2004;6331-9.

228 Moller LB, Petersen C, Lund C, Horn N. Characterization of the hCTR1 gene: genomic organization, functional expression, and identification of a highly homologous processed gene. Gene 2000;257:13-22.

229 Zhou B, Gitschier J. hCTR1: a human gene for copper uptake identified by complementation in yeast. Proc Natl Acad Sci U S A 1997:94(14):7481-6.

230 Culotta VC, Klomp LW, Strain J, Casareno RL, Krems B, Gitlin JD. The copper chaperone for superoxide dismutase. J Biol Chem 1997;272:23469-72.

231 Sturtz LA, Diekert K, Jensen LT, Lill R, Culotta VC. A fraction of yeast Cu, Znsuperoxide dismutase and its metallochaperone, CCS, localize to the intermembrane space of mitochondria. A physiological role for SOD1 in guarding against mitochondrial oxidative damage. J Biol Chem 2001;276:38084-9.

232 Glerum DM, Shtanko A, Tzagoloff A. Characterization of COX17, a yeast gene involved in copper metabolism and assembly of cytochrome oxidase. J Biol Chem 1996;271:14504-9.

233 Amaravadi R, Glerum DM, Tzagoloff A. Isolation of a CDNA encoding the human homolog of COX17, a yeast gene essential for mitochondrial copper recruitment. Hum Genet 1997:99:329-33.

234 Banci L, Bertini I, Del Conte R, D'Onofrio M, Rosato A. Solution structure and backbone dynamics of the $\mathrm{Cu}(I)$ and apo forms of the second metal-binding domain of the Menkes protein ATP7A. Biochemistry 2004;43:3396-403

235 Banci L, Bertini I, Cantini F, DellaMalva N, Herrmann T, Rosato A, Wuthrich K. Solution structure and intermolecular interactions of the third metal-binding domain of ATP7A, the Menkes disease protein. J Biol Chem 2006:281:29141-7.

236 Banci L, Bertini I, Ciofi-Baffoni S, Chasapis CT, Hadjiliadis N, Rosato A. An NMR study of the interaction between the human copper(I) chaperone and the second and fifth metal-binding domains of the Menkes protein. Febs $J$ 2005:272:865-71.

237 DeSilva TM, Veglia G, Opella SJ. Solution structures of the reduced and Cu(I) bound forms of the first metal binding sequence of ATP7A associated with Menkes disease. Proteins 2005;61:1038-49.
238 Jones CE, Daly NL, Cobine PA, Craik DJ, Dameron CT. Structure and metal binding studies of the second copper binding domain of the Menkes ATPase. J Struct Biol 2003;143:209-18.

239 Jensen PY, Bonander N, Karlsson BG, Horn N, Tumer Z, Farver O. Investigation of the copper binding sites in the Menkes disease protein, ATP7A. SSIEM Award. Society of the Study of Inborn Errors of Metabolism. J Inherit Metab Dis 1998;21:195-8

240 Myari A, Hadjiliadis N, Fatemi N, Sarkar B. Copper(I) interaction with model peptides of WD6 and TM6 domains of Wilson ATPase: regulatory and mechanistic implications. J Inorg Biochem 2004:98:1483-94.

241 Forbes JR, Hsi G, Cox DW. Role of the copper-binding domain in the copper transport function of ATP7B, the P-type ATPase defective in Wilson disease. J Biol Chem 1999:274:12408-13.

242 Strausak D, La Fontaine S, Hill J, Firth SD, Lockhart PJ, Mercer JF. The role of GMXCXXC metal binding sites in the copper-induced redistribution of the Menkes protein. J Biol Chem 1999:274:11170-7.

243 Goodyer ID, Jones EE, Monaco AP, Francis MJ. Characterization of the Menkes protein copper-binding domains and their role in copper-induced protein relocalization. Hum Mol Genet 1999;8:1473-8.

244 Lutsenko S Kaplan JH. Organization of P-type ATPases: significance of structural diversity. Biochemistry 1995;34:15607-13.

245 Solioz M, Vulpe C. CPx-type ATPases: a class of P-type ATPases that pump heavy metals. Trends Biochem Sci 1996;21:237-41.

246 Cater MA, Forbes J, La Fontaine S, Cox D, Mercer JF. Intracellular trafficking of the human Wilson protein: the role of the six $\mathrm{N}$-terminal metal-binding sites. Biochem J 2004;380:805-13.

247 Cater MA, La Fontaine S, Mercer JF. Copper binding to the $\mathrm{N}$-terminal metalbinding sites or the CPC motif is not essential for copper-induced trafficking of the human Wilson protein (ATP7B). Biochem J 2007;401:143-53.

248 Petris MJ, Camakaris J, Greenough M, LaFontaine S, Mercer JF. A C-terminal di-leucine is required for localization of the Menkes protein in the trans-Golgi network. Hum Mol Genet 1998;7:2063-71.

249 Francis MJ, Jones EE, Levy ER, Martin RL, Ponnambalam S, Monaco AP. Identification of a di-leucine motif within the $C$ terminus domain of the Menkes disease protein that mediates endocytosis from the plasma membrane. J Cell Sci 1999;1121721-32.

250 Lane C, Petris MJ, Benmerah A, Greenough M, Camakaris J. Studies on endocytic mechanisms of the menkes copper-translocating P-type ATPase (ATP7A; MNK). Endocytosis of the menkes protein. Biometals 2004;17:87-98.

251 Cobbold C, Coventry J, Ponnambalam S, Monaco AP. The Menkes disease ATPase (ATP7A) is internalized via a Racl-regulated, clathrin- and caveolaeindependent pathway. Hum Mol Genet 2003;12:1523-33.

$252 \operatorname{Lim}$ CM, Cater MA, Mercer JF, La Fontaine S. Copper-dependent interaction of glutaredoxin with the $\mathrm{N}$ termini of the copper-ATPases (ATP7A and ATP7B) defective in Menkes and Wilson diseases. Biochem Biophys Res Commun 2006;348:428-36.

253 Lim CM, Cater MA, Mercer JF, La Fontaine S. Copper-dependent interaction of dynactin subunit $\mathrm{p} 62$ with the $\mathrm{N}$ terminus of ATP7B but not ATP7A. J Biol Chem 2006;281:14006-14

254 Ko JH, Son W, Bae GY, Kang JH, Oh W, Yoo OJ. A new hepatocytic isoform of PLZF lacking the BTB domain interacts with ATP7B, the Wilson disease protein, and positively regulates ERK signal transduction. J Cell Biochem 2006;99:719-34.

255 Stephenson SE, Dubach D, Lim CM, Mercer JF, La Fontaine S. A single PDZ domain protein interacts with the Menkes copper ATPase, ATP7A. A new protein implicated in copper homeostasis. J Biol Chem 2005;280:33270-9.

256 Sanokawa-Akakura R, Dai H, Akakura S, Weinstein D, Fajardo JE, Lang SE, Wadsworth S, Siekierka J, Birge RB. A novel role for the immunophilin FKBP52 in copper transport. J Biol Chem 2004;279:27845-8.

257 Schroer TA. Dynactin. Annu Rev Cell Dev Biol 2004;20:759-79.

258 Moller LB, Bukrinsky JT, Molgaard A, Paulsen M, Lund C, Tumer Z, Larsen S, Horn N. Identification and analysis of 21 novel disease-causing amino acid substitutions in the conserved part of ATP7A. Hum Mutat 2005;26:84-93.

259 Tang J, Robertson S, Lem KE, Godwin SC, Kaler SG. Functional copper transport explains neurologic sparing in occipital horn syndrome. Genet Med 2006:8:711-18.

260 lida M, Terada K, Sambongi Y, Wakabayashi T, Miura N, Koyama K, Futai M Sugiyama T. Analysis of functional domains of Wilson disease protein (ATP7B) in Saccharomyces cerevisiae. FEBS Lett 1998:428:281-5. 